This is a self-archived version of an original article. This version may differ from the original in pagination and typographic details.

Author(s): Maliranta, Mika; Nurmi, Satu

Title: Business owners, employees, and firm performance

Year: 2019

Version: Accepted version (Final draft)

Copyright: @ Springer Science+Business Media, LLC, part of Springer Nature 2018.

Rights: In Copyright

Rights url: http://rightsstatements.org/page/InC/1.0/?language=en

Please cite the original version:

Maliranta, M., \& Nurmi, S. (2019). Business owners, employees, and firm performance. Small Business Economics, 52(1), 111-129. https://doi.org/10.1007/s11187-018-0029-1 


\title{
Business owners, employees and firm performance
}

\author{
M ika M aliranta, ETLA \& University of Jyväskylä \\ Satu Nurmi, Statistics Finland \& ETLA
}

The novel Finnish Longitudinal OWNer-Employer-Employee (FLOWN) database was used to analyze how the characteristics of owners and employees relate to firm performance as determined by labor productivity, survival and employment growth. Focusing on the role of the owner's formal education and previous experience as an employee, the results show that previous experience in a high-productivity firm strongly predicts high productivity and probability of survival for the entrepreneur's new firm. This can be interpreted as evidence of knowledge spillover through labor mobility. Strikingly, firms established in times of intensive excess job reallocation were found to exhibit superior productivity performance in the later phases of their life cycles.

JEL codes: L25, L26, J24, J62, 033

Keywords: Entrepreneurship, ownership, firm performance, human capital, diffusion of knowledge

\section{Tiivistelmä}

Tutkimuksessa tarkastellaan sekä yrityksen omistajan että sen työntekijöiden ominaisuuksien yhteyttä yrityksen menestykseen käyttämällä uudenlaista yhdistettyä omistaja-työnantaja-työntekijä-aineistoa (FLOWN). Yrityksen menestystä mitataan työn tuottavuudella, henkiinjäämisellä ja työllisyyskasvulla. Keskitymme erityisesti muodollisen koulutuksen sekä aikaisemman työkokemuksen määrän ja laadun merkitykseen. Tulokset kertovat, että omistajayrittäjän aikaisempi kokemus palkansaajana korkean tuottavuuden yrityksessä ennustaa hänen uudelle yritykselleen korkeaa tuottavuutta ja selviämistodennäköisyyttä. Tulos antaa tukea näkemykselle, että tuottavuutta vahvistava tieto leviää kansantaloudessa, kun työntekijöitä siirtyy korkean tuottavuuden yrityksistä uusiin yrityksiin yrittäjiksi tai työntekijöiksi. Saamme myös kiinnostavaa näyttöä siitä, että intensiivisen työpaikkarakenteen muutoksen aikana syntyneet yritykset ovat tavallista tuottavampia elinkaarensa myöhemmissä vaiheissa.

JEL koodit: L25, L26, J24, J62, 033

Avainsanat: Yrittäjyys, ownership, yrityksen menestys, inhimillinen pääoma, tiedonleviäminen

We thank Ari Hyytinen, Antti Kauhanen and Petri Rouvinen, as well as participants at the XXXVIII Annual Meeting of the Finnish Economic Association in Pori and the ETLA workshop for invaluable comments and suggestions. Part of the data gathering and analysis was carried out at Statistics Finland under its terms and conditions for confidentiality. For access to the data, contact the Researcher Services of Statistics Finland, FI00022 Statistics Finland. The work was supported by TEKES, the Finnish Funding Agency for Technology and Innovation (project 2867/31/2013) and the TT Foundation. 


\section{INTRODUCTION}

Entrepreneurship has been the subject of intensive research and public policy debate for some decades. Recent evidence supports the established view that new businesses create a disproportionate share of new jobs (Haltiwanger, Jarmin, \& M iranda, 2013). However, the associated mechanisms involve intensive market experimentation through entries and exits (Kerr, Nanda, \& Rhodes-Kropf, 2014), with job creation at some firms accompanied by job destruction at others (Davis \& Haltiwanger, 1999; Davis, Haltiwanger, \& Schuh, 1996). Very few new firms achieve the sustained high growth required to make the transition from a small to a large enterprise.

An international comparison shows that a small number of rapidly growing firms account for differences in employment growth between countries (Anyadike-Danes et al., 2015). There is evidence that (young) firms that achieve high productivity can survive and grow, contributing to economic growth through productivityenhancing firm-level restructuring, but significant effects seem to take at least a decade to emerge (Dumont, Rayp, Verschelde, \& M erlevede, 2016; Haltiwanger, Jarmin, Kulick, \& M iranda, 2016; Hyytinen \& Maliranta, 2013). In general, earlier business dynamics research has shown that entrepreneurship can be expected to have a sustained impact on economic growth when based on a firm's ability to achieve high productivity. In addition, the origins of any notew orthy contribution to economic growth may lie far in the firm's past.

Focusing on 'true' entrepreneurs who run limited companies (rather than the self-employed), we find support for the economic impact of productivity-enhancing entrepreneurship (Levine \& Rubinstein, forthcoming). Using the novel Finnish Longitudinal Owner-Employer-Employee Data (FLOWN), this study presents new evidence of how the skills of entrepreneurs contribute to company performance in terms of productivity, survival and growth. More specifically, it will be shown that a formal university education and earlier work experience in a high productivity firm are positively related to the performance of the entrepreneur's own business. This is especially the case when the owner herself works in the firm - that is, the finding pertains especially to entrepreneur-owner firms. With regard to the role of the owner's past work experience, our findings support the view that the importance of entrepreneurs as mediators of economic growth is based on the transfer of knowledge spillovers from high-performing incumbent firms to new (or older) businesses. The present findings also indicate that firms founded at times of intensive micro-level restructuring as measured by the so-called excess job reallocation at the level of establishments (see Davis and Haltiwanger (1999)) can sustain superior productivity, even after many years.

The rest of the paper is organized as follows: Section 2 provides a brief review of the literature. The data are described in Section 3. Section 4 reports the results of our analysis, and Section 5 concludes the paper.

\section{LITERATURE}

The present analysis draws on the literatures related to entrepreneurship, human capital, business dynamics and economic growth to investigate empirically how performance is explained by the human capital of the entrepreneur and her employees, along with multiple other characteristics of the firm and the prevailing economic conditions when the business started. This analysis illuminates the factors underlying firms' productivity, survival and employment growth as the essential elements of the innovation-led micro-level dynamics of productivity and economic growth emphasized in current Schumpeterian growth theory (Aghion, Akcigit, \& Howitt, 2014). 
There is a large literature on factors explaining entrepreneurial choice (Hyytinen, Lahtonen, $\&$ Pajarinen, 2014; Lofstrom, Bates, \& Parker, 2014; Sahaym, Howard, Basu, \& Boeker, 2016) and examining where entrepreneurs come from (Andersson, Baltzopoulos, \& Lööf, 2012; Elfenbein, Hamilton, \& Zenger, 2010; Hyytinen \& M aliranta, 2008; Nanda \& Sørensen, 2010). According to Lazear (2005), rather than specializing in any one skill, entrepreneurs are multi-talented jacks-of-all-trades, and this theory is supported by empirical evidence of the positive relationship between a varied work and educational background and the likelihood of starting one's own business (Stuetzer, Obschonka, \& Schmitt-Rodermund, 2013). There is extensive evidence that the founder's human capital is a crucial determinant of business success (e.g. Bates, 1990; Colombo \& Grilli, 2005; Cooper, Gimeno-Gascon, \& Woo, 1994; Dahlqvist, Davidsson, \& Wiklund, 2000; Shane \& Stuart, 2002), and there is also large literature on the role of personnel characteristics in firm performance (Haltiwanger, Lane, \& Spletzer, 1999, 2007; Ilmakunnas \& M aliranta, 2005). One of the contributions of the present paper is that it grounds these ideas in an exceptionally diverse range of data.

In terms of economic growth, entrepreneurial activity of particular interest can be found where the business owner provides labor input with one or more employees, as such firms are more likely to exhibit growth intentions and an ability to create "good" high productivity jobs. Policy makers should also devote special attention to the role of labor mobility in entrepreneurial activity, as this may be an important channel of knowledge spillover from high-performing incumbent firms to new (or older) businesses. In other words, the effect of the prior experience of entrepreneurs and their employees should be considered more broadly. A number of studies have examined how prior work experience explains entrepreneurial success. At the same time, a growing literature in labor economics shows how employee mobility can contribute to the productivity of the destination firm (e.g. Balsvik, 2011; IImakunnas \& Maliranta, 2016; M aliranta, M ohnen, \& Rouvinen, 2009; Stoyanov \& Zubanov, 2012).

One deficiency of the literature on the effects of human capital on firm performance is that the roles of entrepreneurs and their employees have typically been examined in isolation. The need for a parallel analysis is highlighted by the fact that the skills of entrepreneurs and their staff may be complementary (as suggested for instance by Lazear's (2005) theory). The absence of any such synthesis reflects a lack of data linking business owners, firms and employees over time (Goetz, Hyatt, M cEntarfer, \& Sandusky, forthcoming). To our knowledge, only Rocha, Van Praag, Folta, and Carneiro (2016) have studied the human capital of both founder team and company personnel. However, while they analyze the effect of founders' management and entrepreneurial experience, they fail to provide a broader view encompassing the work experience of entrepreneurs and employees.

In Nordic countries, comprehensive tax-based register data offer new opportunities for empirical analyses of entrepreneurship. Linking data on business owners to their past experience, both in the labor market and as owners of earlier businesses, allows us to study the dynamics of entrepreneurship, business formation and firm performance from a totally new and wider perspective. For example, in Norway, Berglann, Moen, Røed, and Skogstrøm (2011) constructed a more extensive picture of entrepreneurship on the basis of linked register data on ownership.

In most countries, concentrated firm ownership with a single controlling owner has been found to predominate (Claessens, Djankov, \& Lang, 2000; Faccio \& Lang, 2002). In this one-shareholder context, ownership and management are also closely connected, and the influence of managers on firm performance is well documented (Bloom, Genakos, Sadun, \& Van Reenen, 2012)). Based on the universe of limited liability companies, the present study concentrates on owners with a majority share, who have a strong motivation to 
maximize the value of their firm and to control the use of its assets. In particular, we focus here on business owners who are also on the firm's payroll and who are themselves typically involved directly in production, characterized with good reason as entrepreneurs. For the purpose of comparison, separate analyses were also performed on firms where the main owner is not an employee-the so-called 'pure owner' firms. Drawing on novel linked data on business owners, this analysis supplements earlier Finnish studies of entrepreneurship, which include Pajarinen, Rouvinen, and Ylä-Anttila (2006, 2011), Ali-Yrkkö, Pajarinen, Rouvinen, and Ylä-Anttila (2007), Hyytinen and M aliranta (2008), Murray, Hyytinen, and M aula (2009), Tourunen and Laaksonen (2009) and Kontinen and Ojala (2010).

\section{DATA}

In previous studies using the Finnish FLEED, the lack of data linking limited liability companies to owner entrepreneurs represented a serious limitation (M aliranta \& Nurmi, 2004). However, data on the enterprise links of persons defined as entrepreneurs have improved in recent years thanks to the Self-Employed Persons' Pension Act (YEL) and the Farmers' Pension Act (M YEL). Legislation prior to 2011 made pensions obligatory for persons owning more than half of their company stock or voting rights, either alone or with family members. At the beginning of 2011, this threshold was lowered to $30 \%$ for personal ownership (50\% with family members). In addition, that person must be in a leading position and working in the company. Beyond this, detailed information on ownership was not available.

The present study utilizes new register data on ownership from the Finnish Tax Administration. Since 2006, tax returns for business activities have included information on the principal owners of corporate entities. Limited liability companies are obliged to report the personal information of 1-10 shareholders; if there are more than 10, the rule applies to those who own at least $10 \%$ of the capital stock. In addition, every person in receipt of a shareholder loan must also be reported.

By linking information on owners, employers and employees, we have created a new Finnish Longitudinal OWNer-Employer-Employee (FLOWN) database. ${ }^{1}$ For present purposes, this database has been used to focus on 'true' entrepreneurs only, defined as the primary owners of limited liability companies, and the data were extended by new variables describing the histories of owners and personnel. This rich dataset includes the following distinct dimensions.

Owner data includes the personal characteristics and history of the principal owner of each limited liability company; enterprise-level measures of ownership structure were also calculated. (Source: Tax register data, FLEED, Statistics Finland)

Enterprise data includes information on the demographic status and performance of each limited liability company. (Source: Business Register and Financial Statements data, Statistics Finland)

Employee data includes information on the characteristics of personnel in each enterprise and their previous employment relationships. (Source: FLEED)

This linking process was complicated, as enterprises may have multiple person-id or business-id owners, as well as owners with multiple enterprise linkages. We traced ultimate owners through one or two company linkages-for example, if company $A$ is partly $(0.5)$ owned by company $B$, which is in turn partly $(0.5)$ owned by

\footnotetext{
${ }^{1}$ The FLOWN database is available via Statistics Finland's FIONA remote access system. The database links information on the owners of limited liability companies to their firms, with information on dividends by firm and by owner.
} 
person 1 , we define person 1 as one owner of company A with the corresponding share of ownership $(0.5 * 0.5$ $=0.25$ ). As we were unable to differentiate between cash flow rights and voting rights, these were assumed to be equal.

Our target population was Finnish business sector enterprises in 2008 with at least one employee (according to the Business Register). The study examined the performance of manufacturing industries (NACE 2: 15-22, 24-37), construction (45) and services (50-52, 55, 60-64, 70-74) in the period 2009-2013. To measure firm age irrespective of mergers and acquisitions, the age of the oldest establishment was used to create birth cohorts. Information on establishments belonging to the firm is available annually from 1988. The study concentrates on firms with highly concentrated ownership, where it was possible to identify one principal individual owner with a share of more than $50 \%$. These owners were divided into a) entrepreneur-owners (working in the firm that they own) and b) pure owners with no employee status in their firm. Employment status was defined according to end of year data.

Three distinct least-squares models of firm performance were estimated to explain labor productivity (log) levels in 2009 and 2013 and employment growth (log-difference) between the years 2009 and 2013. Firm survival/ exit up to 2013 was estimated using a simple logit model, with separate estimates for entrepreneurowner and pure owner firms. Regressors were measured in 2008 and can be divided into firm attributes (firm size, capital intensity, birth year effects, 2-digit industry); owner attributes (education, general experience/age, work experience in the firm, share of women, previous experience/spillover from another employer) and personnel attributes (similar to those of the owners). The owner's other principal ownerships were also controlled for.

Education is defined in 7 categories in terms of level and field of studies: 0 (basic comprehensive school education, technical (natural sciences or technology)); 1 (vocational or upper secondary); 2 (university of applied sciences or lower university) and 3 (higher university and similar for non-technical education).

Linkages to the previous employer (i.e., the latest other employment relationship found in 2001-2007) were used to evaluate the role of spillovers. Previous work experience was quantified as length of employment relationship and quality of the firm in terms of relative productivity in the industry (two-digit NACE 2), measured as productivity quartiles.

A conventional measure of excess job reallocation was used to describe turbulence in the economy-that is, the difference between job reallocation and the absolute value of net employment change EJR $=J R-|N E T|$, where JR is the sum of job creation and job destruction, and NET is the net employment change (Davis \& Haltiwanger, 1999). Annual EJR was calculated using Statistics Finland's establishment-level job flow database. Excess job reallocation describes the simultaneous job creation and job destruction that is not needed to achieve the given net employment change. Excess job reallocation can result from job flows between different sectors or within sectors, reflecting heterogeneity between firms, reflecting the magnitude of creative destruction in the economy.

Estimations were based on the shares approach from the productivity analysis literature, where the shares of personnel with respect to different attributes (e.g., education and experience) are used as explanatory variables. (Ilmakunnas and Maliranta (2005) used a similar approach to study labor characteristics and wageproductivity gaps.) For the owners, the nature of the data (only one primary owner per firm) meant that shares equalled 0 or 1 . Even though they may have employee status, owners were not included in personnel, enabling stricter comparison between the two groups. 
In the least squares estimations, firm employment in 2008 was used for weighting purposes to obtain results that better reflected the business sector as an aggregate whole, ensuring that the large number of small enterprises would not dominate the results. Weighting the least squares estimations by the number of personnel in the firm has little effect on the results for younger firms, where the size distribution is not unduly skewed. The weighting does make some difference when younger and older firms are pooled for analysis.

\section{EMPIRICAL ANALYSIS}

\subsection{Owners, employees and the success of young firms}

The first part of the analysis began by focusing on young firms established in the period 2003-2008 and their subsequent performance. To properly identify a firm's operational start-up year, plant-level information on entry was used to determine birth cohorts. The findings suggest a definite association between owner and employee history and firm performance. In the second part of the analysis (section 4.2), we pooled the data for young and older cohorts to investigate any possible differences in the results, digging deeper into the incumbents' past and the conditions prevailing at the time of their birth. The analysis reveals clear connections between the magnitude of creative destruction (measured by excess job reallocation at the level of establishments in the business sector) and performance at later stages of firm lifecycle.

To begin, prime owner firms were defined as those limited liability companies for which one individual owner owning more than $50 \%$ of company stock could be identified. These prime owner firms constitute about half of all the limited liability companies in the Finnish private business sector. These firms were further divided into entrepreneur-owner and pure owner, according to the employment status of their prime owner at the end of the year. Owner employees were defined as those having an employment relationship with the firm they primarily owned; pure owners were defined as those who could not be connected to the firm as employees. No account was taken of ownership changes between birth and the period of analysis. In some cases, the primary owner may have changed during the firm's life cycle, but we were especially interested in the influence of characteristics of the owner closest to production in the period before firm performance was measured. Basic characteristics of the 2008 data (both for all birth cohorts and for young firms only) are described in Table 1.

The summary shows that a prime owner is involved in production in about two-thirds of prime owner firms while the prime owner is connected to the firm mainly through cash flows in only a third. For young firms, the situation is more balanced. Somewhat surprisingly, the differences in firm attributes are not striking; pure owner firms are on average slightly larger, but their labor productivity and capital structure remain similar to entrepreneur-owner firms. Up to 2013, young firms were smaller and less likely to survive than the average. However, the probability of survival was on average 10 percentage points higher for entrepreneur-owner firms than for pure owner firms.

A comparison of staff personal characteristics with those of prime owners reveals some distinct differences. Owners are more highly educated than their employees, especially in the case of pure owners of young firms, where $22.6 \%(=4.6 \%+8.0 \%+6.3 \%+3.8 \%)$ of owners have university of applied sciences or higher university degrees while only $10.6 \%(=4.9 \%+2.0 \%+2.5 \%+1.3 \%)$ of staff are highly educated. Across all firms, entrepreneur-owners more often have a technical basic education (30.9\%) than pure owners (22.6\%).

Owners were found to be older and more experienced than their personnel. A majority of owners are 40 or older while employees are younger than 40 . In young firms, owners and employees are clearly younger; half 
of entrepreneur-owners are younger than 40 , and half of their employees are younger than 30 . While most entrepreneur-owners have worked for the firm for 1-10 years, most of their employees have worked there for less than 5 years. Differences in experience between pure owners of young firms and their employees are even greater, with $20.9 \%$ of pure owners close to retirement or retired. Only around $15.0 \%$ of prime entrepreneur-owners and $19.0 \%$ of pure owners are women. For younger cohorts, these shares are slightly higher.

We were particularly interested in how owners' and employees' previous experience influenced the performance of their current firm, based on two aspects of that previous experience: length and quality (where quality is defined as relative productivity level within that industry for their last previous employment during the period 2001-2007). Working history was traceable for about half of the (employee) owners and employees. Unsurprisingly, previous employment spells can more often be traced for owners and employees of younger firms; of the remainder, those with no experience in another firm may be working in the same firm as in 2008 , or defined as self-employed, unemployed or students. As expected, a small share (3.8\%) of owners in young entrepreneur-owner firms had at least 15 years' experience in the previous firm while a relatively large percentage (40.9\%) of owners in entrepreneur-owner firms had 1-5 years' experience in the previous firm.

Quality of previous experience was defined as the relative productivity of the previous employer by industryspecific productivity quartile; ${ }^{2}$ missing links or missing information meant that this could not be not be specified for all firms. Labor productivity was calculated only for firms with at least one employee, and some production data were based on information from the previous or following year. In some cases, the previous employer might be a public sector organization with no value added or a small 'natural person' firm. For young firms, the performance of the previous employer can be defined for two thirds of the entrepreneurowners and half of the pure owners. For the pooled sample, previous employer productivity can be determined only for every fourth (employee) owner. For employees, the figures are person-weighted averages. Information about previous experience could be traced for every second employee. For $80 \%$ of firms, some information could be found on employees' previous experience, and for $75 \%$ of firms, information on past productivity was available for at least one employee (not shown in the table).

M ore interesting observations can be made about patterns related to the productivity of the previous firm/employer. The largest percentage of owners come from the highest quartile firms, and the fewest come from the lowest quartile firms; these patterns are consistent for both entrepreneur-owner firms and pure owner firms and among both young firms and all firms, suggesting mobility among owners away from highproductivity firms. These dynamics are consistent with the view that owner mobility is potentially an important mechanism of productivity spillover between firms, including spillover from older to newer production. The comparison with corresponding patterns for employees is very interesting, showing that a significant percentage of employees had worked in a relatively low-productivity firm, suggesting employee mobility away from low-productivity firms. These patterns are consistent with the view that employee mobility is one element of productivity-enhancing restructuring (i.e., creative destruction).

We also examined the sectoral distribution of owners and the differences in their characteristics across sectors, as shown in Appendix Tables A1 and A2; here, we describe some selected features. A great number of entrepreneur-owner firms are in construction, professional activities, wholesale and retail trade and

\footnotetext{
${ }^{2}$ In other words, we measured the relative productivity level within industries classified at about 2-digit industry level.
} 
transportation and storage, and pure owner firms are also well represented in those same sectors. The percentage of highly and technically educated individuals varies considerably between sectors; in most sectors, entrepreneur-owners are more highly educated and technically oriented than their employees. For pure owners, the situation is reversed for technical orientation, as employees have on average more technical education than owners in many sectors. In sectors where the percentage of female employees is high (accommodation, food and textile industries), the share of women owners is higher than usual at around $30 \%$.

The results of the econometric models for young entrepreneur-owner firms are presented in Table 2 and for young pure owners in Table 3. We compare the importance of owner and employee characteristics for firm performance, measured in terms of labor productivity (in 2009 and 2013), probability of survival (2009-2013) and employment growth (2009-2013). In addition to personal characteristics, we controlled for firm size, age, number of primary ownerships (>1), capital structure and sector in 2008.

Estimates based on educational attainment reveal that higher university level education of the prime owner in 2008 is strongly positively related to firm labor productivity in 2009 (and in 2013). For example, the results suggest that a firm whose entrepreneur-owner has a technical higher university education is $22.9 \%$ more productive than an otherwise similar firm whose entrepreneur-owner has only a basic education.

Interestingly, there is no equivalent effect for employees. However, when the variables controlling education and other owner characteristics are omitted from the model, the effect of employee technical higher university education becomes economically $(0.250)$ and statistically $(p=0.05)$ significant (results are not reported here), confirming a need to control owner and employee effects together. The results also suggest that owner technical education increases survival probability, but owner education appears unrelated to firm employment growth. Findings on growth remain similar even when controlling for sample selection bias resulting from the (more likely) exit of smaller firms from the sample, using the Heckman two-step model (preliminary results are not reported here).

Estimates of the effects of general experience (age) suggest a hump-shaped pattern in effect on survival, peaking in the 41-50 age group for both owners and employees. Generally, however, age structure has little predictive power for performance among young firms. While owner gender seems to have no effect on productivity, there is some indication that percentage of female employees is negatively related to (current) productivity level but positively related to survival.

Perhaps the most interesting results pertain to the effects of previous experience (in terms of length and quality). As Table 2 indicates, length of previous experience of entrepreneur-owners is generally unrelated to firm performance. However, there is a strong positive relationship between the productivity level of the previous firm and firm performance in terms of productivity and survival (but not employment growth). Our estimates suggest that a new firm whose entrepreneur-owner has had experience at a high-productivity firm is $10.9 \%$ more productive in 2009 (11.5\% in 2013) and has a 7.5\% higher probability of survival than an otherwise similar firm whose entrepreneur-owner has had experience at a low-productivity firm. However, no significant difference was found between these firms in terms of employment growth. So, in addition to the stronger mobility of owners away from high-productivity firms than from lower-productivity firms (see Table 1), these results suggest that the flow of entrepreneur-owners from high-productivity firms is reflected in the performance of young destination firms.

Corresponding results for employees of the entrepreneur-owner firms suggest a substantially stronger relationship between the performance of previous and current firm. According to the estimates, a new firm whose employees all come from a high-productivity firm is $23.9 \%$ more productive and has a survival 
probability $8.6 \%$ higher than an otherwise similar firm whose employees all come from a low-productivity firm. While we interpret these results as indicative of spillover, it is important to acknowledge that other mechanisms may also be at play here. It can be argued, for example, that the matching of high-skilled employees with high-technology firms may be reflected in the transitions of employees from high- (or low)productivity firms to other high- (or low-)productivity firms (Ehrl, 2014). Nevertheless, it is notable that owners of new high-productivity firms often come from older high-productivity firms where they worked as employees.

Table 3 reports the results for young pure owner firms; some key findings will be briefly reported here. Generally, characteristics of pure owners are more weakly related to firm performance. However, a pure owner with a technical higher university education has a significant positive effect on productivity in 2009 once controls for employee characteristics are dropped. One interesting exception is the strong negative relationship between pure owner age (general experience) and productivity level in 2013. Another exception is that high productivity is positively related to relatively long experience (10-15 years) at the previous firm. Contrary to our findings for entrepreneur-owner firms, no relationship was found between the productivity level of the previous firm and the productivity level or survival of the pure owner's firm.

Additionally, the coefficients of the model suggest that, among employees of pure owner firms, previous employer performance is particularly important in explaining productivity differences. The results indicate that a young firm whose employees all come from a high-productivity firm is at least $38.3 \%$ more productive in 2009 (41.4\% in 2013) and has a $13.3 \%$ larger survival probability than an otherwise similar firm where all employees come from a low-productivity previous employer. The effects of employee characteristics for entrepreneur-owner and pure owner firms are more similar, though somewhat less precise for pure owner firms, perhaps in part because of a smaller sample size. While productivity level is negatively related to percentage of female employees, previous employer productivity level is strongly positively related to current employer productivity level in 2009 and 2013.

These findings broadly correspond to those of earlier studies; for example, Ilmakunnas and Maliranta (2005) reported the positive effect on productivity of education and the negative effect of younger and less experienced staff. While Rocha et al. (2016) found that firm performance benefits from the quantity and quality of founders' human capital, they also found that owner and workforce quality had stronger effects on employment growth.

\subsection{Older generations and the effect of business conditions on future performance}

In the second part of the analysis, we pooled young and older firms into the same sample. This has three advantages. First, a larger sample provided more degrees of freedom, yielding statistically more precise estimates. Second, a comparison of the results of our previous analysis of only young firms with pooled data results enabled the identification of any differences in effects between younger and older firms. Finally, and perhaps most interestingly, pooling young and older firms enabled analysis of how economic conditions in a firm's birth year are reflected in its performance up to 20 years later.

The birth year of a firm (or firm cohort) was determined on the basis of the firm's oldest establishment. By linking firm- and establishment-level data, we were able to trace firm birth year back as far as 1989. Our regression models of firm performance included a set of dummy variables for firm birth year, using firms born in 1988 or earlier as a reference group. As well as controls for firm birth year, previous models for the pooled data were estimated by adding length of seniority of owners and employees to measure the effects of firm- 
specific work experience. The larger sample enabled more precise estimation of the effects of entrepreneurowner and employee characteristics, providing a clearer indication that education level is strongly related to firm productivity. However, in economic terms, the effects are generally smaller for entrepreneur-owners than for employees. In particular, there is a very strong relationship between the educational level of employees (measured in 2008) and productivity in 2013 (and less so in 2009). One interpretation of this difference is that the productivity effect of a higher education takes time to emerge because the mechanism involves time-consuming innovation efforts. There is also evidence that higher education among both entrepreneur-owners and employees increases survival probability.

There is no indication that productivity increases with entrepreneur-owner or employee age, but employee seniority was found to be positively related to productivity in 2013. According to the estimates, female entrepreneur-owners' firms have lower productivity levels than those of males, but there is no difference in survival probability or employment growth. We also found that the effect of gender on productivity is stronger for employees than for entrepreneur-owners.

Length of experience of entrepreneur-owners in the previous firm does not affect productivity (as was true of young firms only). In the pooled data, no relationship was found between employees' length of experience of in the previous firm and firm productivity level. This contrasts with our earlier finding for young firms that low productivity level in 2009 is associated with a high percentage of employees with little previous experience (less than one year) or none. However, this gap vanishes for productivity in 2013. One possible explanation for this is that the experience obtained in the current firm compensates for employees' initial lack of experiencebased human capital. As shown in Table 1,72.7\% (=100.0\% - 27.3\%) of employees in young entrepreneurowner firms had at least some previous experience in another firm. The corresponding number for all entrepreneur-owner firms is $54.3 \%(=100.0 \%-45.7 \%)$. Overall, the employees of young firms have more previous experience in another firm than the employees of older firms.

Results from the pooled data confirm the earlier findings for young firms that previous employer productivity is strongly positively related to current productivity level and survival probability for entrepreneur-owners and employees. This suggests that the role of productivity spillover is not confined to young firms. These effects are less clear for pure owners, suggesting that owner involvement in production is important for transfer of information and implementation of new technologies. However, a smaller sample and larger standard errors prevent any strong conclusions.

As a final step, the analysis was extended to investigate more thoroughly the birth cohort effects from previous models for entrepreneur-owner firms. Figure 1.a shows estimated cohort effects on productivity in 2009 and 2013, and Figure 1.b shows cohort effects on survival probability and employment growth. Figure 1.a suggests, for example, that when controlling for a wide array of variables in our regression model, firms established in 1995 were 3.1\% more productive in 2009 than firms established in 1988 or earlier. Figure 1.b shows that firms established in 1995 had 2.8\% lower survival probability and 1.9\% lower employment growth from 2009 to 2013 than firms established in 1988 or earlier. While there are considerable short-term fluctuations in cohort effects, these patterns generally indicate that younger firms exhibit lower productivity (especially when measured in 2009) and lower survival probability; on the other hand, surviving young firms exhibit higher employment growth when compared to older firms, broadly aligning with the evidence from the firm growth literature (Caves, 1998; Haltiwanger et al., 2013; Sutton, 1997).

Clearly, part of the short-term variation in cohort effects can be attributed to statistical noise. However, the issue of immediate interest is whether other factors might explain the differences in cohort effects for 
different years, so clarifying whether economic conditions at the time of a firm's foundation affect productivity in years to come. For example, what might explain the finding that firms founded in 1995 were more productive in 2009 than those founded in 1999?

Among the interesting factors that might explain such differences are those related to creative destruction, involving the simultaneous destruction of jobs in some firms (or establishments) and the creation of new jobs in others. Based on variants of the productivity decomposition method, there is increasing evidence that a sizable proportion of aggregate productivity growth can be attributed to job reallocation at the level of firms and establishments (e.g. Balk, 2016; Foster, Haltiwanger, \& Krizan, 2001; Petrin \& Levinsohn, 2012; Van Biesebroeck, 2008). Hyytinen and M aliranta (2013) showed that creative destruction varies in form over a firm's life cycle. New firm entry initially contributes negatively to aggregate productivity growth because such firms, on average, exhibit relatively low productivity. Their positive effect emerges gradually over time, as young low-productivity firms have abnormally high exit rates and young high-productivity firms grow faster than others.

The present study examines how entrants' performance in later years relates to intensity of job reallocation, an essential part of creative destruction measured by excess job reallocation (EJR). Figure 2 shows excess job reallocation rate (one-year lag) in the Finnish business sector (right axis) graphed against cohort effect on productivity in 2009 (left axis) as already seen in Figure 1.a. Visual inspection confirms the remarkable resemblance between these phenomena. Firms born in years of intensive job reallocation have higher productivity in 2009; one explanation is that challenging economic conditions make firms especially careful in their choice of technology at the beginning of their life cycle, and this is reflected in their subsequent performance.

Statistical analysis of the relationship between volatility at birth and firm performance involved estimation of how annual excess job reallocation (one-year lag) affected point estimates of the effect of birth year on labor productivity (2009), survival and employment growth, based on the previous regression models for all entrepreneur-ownerentrepreneur-owner and pure owner firms, respectively. The explanatory variable (excess job reallocation) was measured with a one-year lag because it clearly provides a better empirical fit than the current value for excess job reallocation. An intuitive explanation for this lag is that the decision to establish a firm is made some time before actual entry.

Table 4 summarizes six time-series estimations: three dependent variables (cohort effects for productivity, survival probability and employment growth), estimated separately for entrepreneur-owner firms and pure owner firms. In addition to the indicator of excess job reallocation rate, these time-series regressions include controls for recession years 1992-1993 and the time trend. The results indicate an economically strong and statistically significant relationship between excess job reallocation and the cohort effect of productivity levels for entrepreneur-owner firms. The coefficient implies that a one percentage-point increase in excess job reallocation increases the productivity level of the cohort by $2.4 \%$; for pure owner firms, the corresponding figure is $1.9 \%$ (and the coefficient is also statistically significant). The results for entrepreneur-owner enterprises also show that firms established during the severe recession in 1992-1993 were 18.7\% more productive than might be expected on the basis of job reallocation intensity during that period. (Note that excess job reallocation slumped during these recession years.) The corresponding figure for pure owner firms is $16.1 \%$. There is a weak or absent relationship between excess job reallocation and survival probability and employment growth in 2009-2013 for both entrepreneur-owner and pure owner firms. Interestingly, entrepreneur-owner firms founded in the recession years 1992-1993 had an abnormally low probability of 
survival in 2009-2013. Finally, Figure 3 graphs observed birth year effects against the predictions of these models. While the time-series regression can be seen to predict very closely the birth year effect of productivity level, as well as survival probability for entrepreneur-owner firms, the fit for pure owner firms is much less satisfactory.

\subsection{Further robustness checks}

A number of robustness checks were performed in the course of the analysis. Beyond those mentioned above, this section summarizes some of the most interesting findings. As a natural extension, measuring firm performance by average wages per employee rather than labor productivity does not markedly alter the main findings, with similar or even stronger effects of both entrepreneur-owner and employee technical university education on firm performance for all firms and young firms. While spillover from previous firms resembles productivity estimations in 2009, both owner and employee quality effects for wage rate in 2013 are mostly statistically insignificant. For pure owner firms, there is some evidence that employee mobility from highproductivity firms is also reflected in 2013 wage level. As expected, there is a clear positive connection between firm size and level of wages.

With regard to the identification of owners, primary owners identified in the tax registers were compared to the FLEED definition of entrepreneurs, based on the Self-Employed Persons' Pension Act. This information is restricted to owners who have an employment relationship with the firm. Based on preliminary calculations, results using the FLEED information resembles our findings for entrepreneur-owners using FLOWN data. It should be noted that Statistics Finland revised its system for production of business statistics in 2013. Given these changes in the definition of statistical units and the harmonization of some firm classifications, this may result in time series breaks. However, measuring productivity or employment growth to 2012 rather than 2013 does not markedly alter our main conclusions.

Further analysis is needed to identify the mechanisms behind long-run productivity paths. Entering and exiting firms may distort the picture, as spillover through owner and employee mobility may accrue from both exiting and continuing firms. It would be interesting to investigate the role of workers coming from outside the labor force or the length and quality of the owner's previous entrepreneurial experience. The analysis of effects of excess job reallocation could also be extended to include firms with multiple personal owners. In addition, it would be worth repeating the analysis for different sectors of the economy to determine whether there are differences in this regard between manufacturing and services, for example. To extend the timeframe, the situation in 2006 (prior to the financial crisis) could also be analyzed.

\section{CONLUDING REM ARKS}

How the characteristics of owner entrepreneurs and their employees affect firm performance and economic growth remains poorly understood in the literature. By creating a new dataset with significant research potential linking owner, employer and employee, this paper opens up novel perspectives illuminating the impact of entrepreneurial skills on economic growth, so informing policy debate on the effects of ownership, education and economic conditions on firm performance.

The diversified paths of primary owners and their employees are reflected in future company performance. Previous employer quality, measured in terms of relative productivity, is transferred through owners and employees as knowledge spillover related, for example, to technology or management. High-quality owners 
create firms capable of achieving and maintaining sustained high performance in terms of productivity, survival and employment growth.

Our results lend support to the view that employees' entrepreneurial skills nurtured in high-productivity firms can be transferred to achieve higher productivity, especially in entrepreneur-owner firms. First, there is a strong positive relationship between the productivity level of the previous firm (where the owner worked as an employee) and the productivity level of the firm where the owner now works. Second, there is evidence of considerable employee mobility from high-productivity firms to ownership of a new firm (where the owner also works). These findings are consistent with the view that the transition of employees from highproductivity firms to entrepreneurship is an important business dynamic, driving knowledge spillover in the economy. Our results also indicate intensive employee mobility from low-productivity firms toward new and young firms, representing an important element of creative destruction. The reallocation of employees in creative destruction means that a greater share of the employees provide labor inputs to productively managed firms (Bloom, Sadun, \& Van Reenen, 2016).

The present analysis demonstrates that identification of owners is crucial for understanding company life cycles. Young firms have relatively younger and more educated human capital but are more dependent on the inflow of knowhow from more experienced firms. There are other interesting differences between younger and older firm cohorts in terms of human capital effects, and lessons can be learned from the history of older generations, including the evidence here that firms established at times of intensive restructuring are subsequently more productive.

One possible explanation for our finding that high-productivity firms are established at times of intensive excess job reallocation relates to the patterns of labor mobility from employment to entrepreneurship; it can be hypothesized that, at times of intensive restructuring, an increasing percentage of employees in highproductivity firms see opportunities for high-performing businesses of their own. In other words, excess job reallocation may provide a suitable indicator of so-called 'opportunity entrepreneurship'. We found that entrepreneur-owners of new high-productivity firms had typically made a transition from employment in a high-productivity firm. If such transitions are most common at times of intensive restructuring, one would also expect to find that those firm cohorts are particularly productive in subsequent years, as documented here; indeed, the literature confirms the persistence of productivity differences over time (Bartelsman \& Doms, 2000).

At this point, it is important to note the absence of any clear relationship between excess job reallocation and business cycles. In the Finnish business sector, excess job reallocation has been intensive at times of both low unemployment (1989-90) and high unemployment (1994-96), with an increase in 1997-2002, when the unemployment rate was in steady decline. Clearly, then, factors other than business cycle effects are likely to play a role, including labor and product market regulations (Haltiwanger, Scarpetta, \& Schweiger, 2014) or trade liberalization (Bernard, Redding, \& Schott, 2007).

Our results demonstrate the importance of considering owner and employee characteristics separately but in parallel in any analysis of firm performance, as owner and employee background and skills may play different roles in the development of employment and productivity. In addition, this analysis indicates a need to deal separately with entrepreneur-owner and pure owner firms. In entrepreneur-owner firms, an owner's technically orientated education was found to impact positively on productivity performance and survival probability, but no such relationship was found in pure owner firms. One explanation for this difference is that closer owner links to production are needed to successfully exploit technical education and previous 
experience. In contrast, the potential contribution of pure owners pertains to factors that cannot be captured by measures of education and experience.

This also relates to definitions of entrepreneurs and entrepreneurship. The present analysis illuminates entrepreneurial performance when we rely on a narrower definition of entrepreneur as requiring both strict (majority) control of ownership and direct involvement in production as an employee of the firm. For entrepreneurs who meet only the broader definition of having majority control but no direct involvement through employment, we were unable to establish any clear empirical relationship with owner characteristics. The analyses did however reveal a number of important empirical relationships concerning the characteristics of employees of pure owner firms. These findings are unsurprising in cases where entrepreneurs are multitalented jack-of-all-trades with no single specialized skill and so hire professionals with specialized education and/or experience, as described in Lazear's (2005) theory.

The present study provides a starting point for closer analysis of owner entrepreneurs and their importance for the wider economy. In future work, we aim to identify truly entrepreneurial start-ups with the greatest growth potential. We are also interested in the productivity effects of a more diversified ownership structure and multiple owners. Finally, future research should devote more attention to the underlying mechanisms connecting initial business conditions and creative destruction to firms' long-run productivity. 


\section{References}

Aghion, P., Akcigit, U., \& Howitt, P. (2014). Chapter 1 - What Do We Learn From Schumpeterian Growth Theory? In A. Philippe \& N. D. Steven (Eds.), Handbook of Economic Growth (Vol. Volume 2, pp. 515-563): Elsevier.

Ali-Yrkkö, J., Pajarinen, M., Rouvinen, P., \& Ylä-Anttila, P. (2007). Family Businesses and globalization in Finland. Available at SSRN 981129.

Andersson, M., Baltzopoulos, A., \& Lööf, H. (2012). R\&D strategies and entrepreneurial spawning. Research Policy, 41(1), 54-68.

Anyadike-Danes, M., Bjuggren, C.-M., Gottschalk, S., Hölzl, W., Johansson, D., Maliranta, M., \& Myrann, A. (2015). An international cohort comparison of size effects on job growth. Small Business Economics, 44(4), 821-844.

Balk, B. M. (2016). The Dynamics of Productivity Change: A Review of the Bottom-Up Approach. In W. H. Greene, L. Khalaf, C. , R. Sickles, M. Veall \& M.-C. Voia (Eds.), Productivity and Efficiency Analysis (pp. 15-49): Springer.

Balsvik, R. (2011). Is labor mobility a channel for spillovers from multinationals? Evidence from Norwegian manufacturing. The Review of Economics and Statistics, 93(1), 285-297.

Bartelsman, E. J., \& Doms, M. (2000). Understanding Productivity: Lessons from Longitudinal Microdata. [Article]. Journal of Economic Literature, 38(3), 569-594.

Bates, T. (1990). Entrepreneur human capital inputs and small business longevity. The review of Economics and Statistics, 551-559.

Berglann, H., Moen, E. R., Røed, K., \& Skogstrøm, J. F. (2011). Entrepreneurship: Origins and returns. Labour Economics, 18(2), 180-193.

Bernard, A. B., Redding, S. J., \& Schott, P. K. (2007). Comparative advantage and heterogeneous firms. The Review of Economic Studies, 74(1), 31-66.

Bloom, N., Genakos, C., Sadun, R., \& Van Reenen, J. (2012). Management Practices Across Firms and Countries. [Article]. Academy of Management Perspectives, 26(1), 12-33. doi: 10.5465/amp.2011.0077

Bloom, N., Sadun, R., \& Van Reenen, J. (2016). Management as a Technology? Harvard Business School Strategy Unit Working Paper(16-133).

Caves, R. E. (1998). Industrial organization and new findings on the turnover and mobility of firms. Journal of Economic Literature, 36(4), 1947.

Claessens, S., Djankov, S., \& Lang, L. H. (2000). The separation of ownership and control in East Asian corporations. Journal of financial Economics, 58(1), 81-112.

Colombo, M. G., \& Grilli, L. (2005). Founders' human capital and the growth of new technologybased firms: A competence-based view. Research policy, 34(6), 795-816.

Cooper, A. C., Gimeno-Gascon, F. J., \& Woo, C. Y. (1994). Initial human and financial capital as predictors of new venture performance. Journal of Business Venturing, 9(5), 371-395.

Dahlqvist, J., Davidsson, P., \& Wiklund, J. (2000). Initial conditions as predictors of new venture performance: A replication and extension of the Cooper et al. study. Enterprise and Innovation Management Studies, 1(1), 1-17.

Davis, S. J., \& Haltiwanger, J. (1999). Gross Job Flows. In O. C. Ashenfelter \& D. Card (Eds.), Handbook of Labor Economics, Volume 3B: Elsevier.

Davis, S. J., Haltiwanger, J., \& Schuh, S. (1996). Small Business and Job Creation: Dissecting the Myth and Reassessing the Facts. Small Business Economics, 8(4), 297-315.

Dumont, M., Rayp, G., Verschelde, M., \& Merlevede, B. (2016). The contribution of start-ups and young firms to industry-level efficiency growth. Applied Economics, 1-16.

Ehrl, P. (2014). High-wage workers and high-productivity firms-a regional view on matching in Germany. 
Elfenbein, D. W., Hamilton, B. H., \& Zenger, T. R. (2010). The Small Firm Effect and the Entrepreneurial Spawning of Scientists and Engineers. Management Science, 56(4), 659-681. doi: doi:10.1287/mnsc.1090.1130

Faccio, M., \& Lang, L. H. (2002). The ultimate ownership of Western European corporations. Journal of financial economics, 65(3), 365-395.

Foster, L., Haltiwanger, J., \& Krizan, C. J. (2001). Aggregate Productivity Growth: Lessons from Microeconomic Evidence. In C. R. Hulten, E. R. Dean \& M. J. Harper (Eds.), New developments in productivity analysis (pp. 303-363). Chicago and London: University of Chicago Press.

Goetz, C., Hyatt, H. R., McEntarfer, E., \& Sandusky, K. (forthcoming). The Promise and Potential of Linked Employer-Employee Data for Entrepreneurship Research. In J. Haltiwanger, E. Hurst, J. Miranda \& A. Schoar (Eds.), Measuring Entrepreneurial Businesses: Current Knowledge and Challenges: University of Chicago Press.

Haltiwanger, J., Jarmin, R. S., Kulick, R., \& Miranda, J. (2016). High Growth Young Firms: Contribution to Job, Output, and Productivity Growth Measuring Entrepreneurial Businesses: Current Knowledge and Challenges: University of Chicago Press (available at http://www.nber.org/chapters/c13492.pdf ).

Haltiwanger, J., Jarmin, R. S., \& Miranda, J. (2013). Who creates jobs? Small versus large versus young. Review of Economics and Statistics, 95(2), 347-361.

Haltiwanger, J., Scarpetta, S., \& Schweiger, H. (2014). Cross country differences in job reallocation: The role of industry, firm size and regulations. Labour Economics, 26(0), 11-25. doi: http://dx.doi.org/10.1016/j.labeco.2013.10.001

Haltiwanger, J. C., Lane, J. I., \& Spletzer, J. R. (1999). Productivity Differences across Employers: The Roles of Employer Size, Age, and Human Capital. American Economic Review, 89(2), 94-98.

Haltiwanger, J. C., Lane, J. I., \& Spletzer, J. R. (2007). Wages, Productivity, and the Dynamic Interaction of Businesses and Workers. Labour Economics, 14(3), 575-602.

Hyytinen, A., Lahtonen, J., \& Pajarinen, M. (2014). Forecasting Errors of New Venture Survival. Strategic Entrepreneurship Journal, 8(4), 283-302.

Hyytinen, A., \& Maliranta, M. (2008). When Do Employees Leave Their Job for Entrepreneurship? Scandinavian Journal of Economics, 110(1), 1-21.

Hyytinen, A., \& Maliranta, M. (2013). Firm lifecycles and evolution of industry productivity. Research Policy, 42(5), 1080-1098. doi: http://dx.doi.org/10.1016/j.respol.2013.01.008

Ilmakunnas, P., \& Maliranta, M. (2005). Technology, labour characteristics and wage-productivity gaps. Oxford Bulletin of Economics and Statistics, 67(5), 623-644.

IImakunnas, P., \& Maliranta, m. (2016). How does the age structure of worker flows affect firm performance? Journal of Productivity Analysis, forthcoming. doi: 10.1007/s11123-016-0471-5

Kerr, W. R., Nanda, R., \& Rhodes-Kropf, M. (2014). Entrepreneurship as Experimentation. Journal of Economic Perspectives, 28(3), 25-48.

Kontinen, T., \& Ojala, A. (2010). Internationalization pathways of family SMEs: Psychic distance as a focal point. Journal of Small Business and Enterprise Development, 17(3), 437-454.

Lazear, E. P. (2005). Entrepreneurship. Journal of Labor Economics, 23(4), 649-680. doi: doi:10.1086/491605

Levine, R., \& Rubinstein, Y. (forthcoming). Smart and Illicit: Who Becomes an Entrepreneur and Do They Earn More? Quarterly Journal of Economics.

Lofstrom, M., Bates, T., \& Parker, S. C. (2014). Why are some people more likely to become smallbusinesses owners than others: Entrepreneurship entry and industry-specific barriers. Journal of Business Venturing, 29(2), 232-251. doi: http://dx.doi.org/10.1016/j.jbusvent.2013.01.004

Maliranta, M., Mohnen, P., \& Rouvinen, P. (2009). Is Inter-Firm Labor Mobility a Channel of Knowledge Spillovers? Evidence form a Linked Employer-Employee Panel. Industrial and Corporate Change, 18(6), 1161-1191.

Maliranta, M., \& Nurmi, S. (2004). Analyzing entrepreneurship with the Finnish linked employeremployee data FLEED. Matching and qualitative properties of the data. The Research Institute of the Finnish Economy (ETLA), Discussion papers No. 920. Helsinki. 
Murray, G., Hyytinen, A., \& Maula, M. (2009). Growth entrepreneurship and finance. Chapters, 147202.

Nanda, R., \& Sørensen, J. B. (2010). Workplace Peers and Entrepreneurship. Management Science, 56(7), 1116-1126. doi: doi:10.1287/mnsc.1100.1179

Pajarinen, M., Rouvinen, P., \& Ylä-Anttila, P. (2006). Uusyrittäjien kasvuhakuisuus. ETLA Discussion Papers, The Research Institute of the Finnish Economy (ETLA).

Pajarinen, M., Rouvinen, P., \& Ylä-Anttila, P. (2011). Omistajuuden vaikutus suomalaisen työllisyyden kasvuun ja pysyvyyteen.

Petrin, A., \& Levinsohn, J. (2012). Measuring aggregate productivity growth using plant level data. The RAND Journal of Economics, 43(4), 705-725.

Rocha, V., Van Praag, M., Folta, T. B., \& Carneiro, A. J. M. (2016). Entrepreneurial Choices of Initial Human Capital Endowments and New Venture Success. IZA, DP No. 9919.

Sahaym, A., Howard, M. D., Basu, S., \& Boeker, W. (2016). The parent's legacy: Firm founders and technological choice. Journal of Business Research, 69(8), 2624-2633. doi: http://dx.doi.org/10.1016/j.jbusres.2016.04.012

Shane, S., \& Stuart, T. (2002). Organizational endowments and the performance of university startups. Management science, 48(1), 154-170.

Stoyanov, A., \& Zubanov, N. (2012). Productivity Spillovers Across Firms through Worker Mobility. American Economic Journal: Applied Economics, 4(2), 168-198. doi: http://dx.doi.org/10.1257/app.4.2.168

Stuetzer, M., Obschonka, M., \& Schmitt-Rodermund, E. (2013). Balanced skills among nascent entrepreneurs. Small Business Economics, 41(1), 93-114.

Sutton, J. (1997). Gibrat's legacy. Journal of economic literature, 35(1), 40-59.

Tourunen, K., \& Laaksonen, S. (2009). The Significance of Business Ownership and Governance: Contribution and Profitability of Family Businesses in Finland.

Van Biesebroeck, J. (2008). Aggregating and Decomposing Productivity. Review of Business and Economics, 53(2), 122-146. 
Table 1. Summary statistics for young firms and all firms: primary owners and employees

\section{Means}

No. of firms

Firm size

Log labor productivity

Log capital intensity

Survival prob. (\%)

Shares of (\%)

\section{Education}

Basic education

Non-technical vocational

Non-technical lower university

Non-technical higher university

Technical vocational

Technical lower university

Technical higher university

\section{Experience in the firm}

\section{$<1$ year}

$1-5$ years

5-10 years

$10-15$ years

$15+$ years

\section{Age (general experience)}

$<30$ years

$31-40$ years

41-50 years

51-60 years

$61+$ years
YOUNG FIRMS

\begin{tabular}{|c|c|}
\hline $\begin{array}{r}\begin{array}{r}\text { Entrepreneur-owner } \\
\text { firms }\end{array} \\
\end{array}$ & $\begin{array}{r}\text { Pure owner } \\
\text { firms } \\
\end{array}$ \\
\hline 3154 & 2422 \\
\hline 4,3 & 4,5 \\
\hline 10,6 & 10,5 \\
\hline 9,0 & 9,2 \\
\hline 69,5 & 59,1 \\
\hline
\end{tabular}

Ow

$\begin{array}{rrrr}22,2 & 26,5 & 20,8 & 28,5 \\ 30,3 & 33,9 & 33,7 & 37,4 \\ 3,6 & 4,2 & 4,6 & 4,9 \\ 4,9 & 2,5 & 8,0 & 2,0 \\ 27,3 & 27,5 & 22,9 & 23,4 \\ 7,2 & 3,7 & 6,3 & 2,5 \\ 4,5 & 1,7 & 3,8 & 1,3\end{array}$

$\begin{array}{rr}13,4 & 60,6 \\ 74,4 & 37,8 \\ 12,2 & 1,6\end{array}$

62,6

36,0

1,4

$\begin{array}{rrrr}15,2 & 46,4 & 10,6 & 47,0 \\ 35,8 & 23,0 & 29,0 & 21,2 \\ 31,8 & 18,1 & 33,2 & 17,7 \\ 15,3 & 10,3 & 19,5 & 11,7 \\ 1,9 & 2,2 & 7,7 & 2,4\end{array}$

ALL FIRMS

\begin{tabular}{|c|c|c|c|}
\hline Entrepr & $\begin{array}{r}\text { peur-owner } \\
\text { firms }\end{array}$ & & $\begin{array}{r}\text { Pure owner } \\
\text { firms }\end{array}$ \\
\hline & 17798 & & 9968 \\
\hline & 6,8 & & 9,4 \\
\hline & 10,8 & & 10,7 \\
\hline & 9,5 & & 9,5 \\
\hline & 79,4 & & 69,1 \\
\hline Owners & Employees & Owners & Employees \\
\hline
\end{tabular}

\begin{tabular}{|c|c|c|c|}
\hline 22,1 & 24,8 & 22,1 & 23,7 \\
\hline 29,9 & 34,4 & 32,8 & 34,3 \\
\hline 2,7 & 3,7 & 4,2 & 4,2 \\
\hline 4,2 & 1,6 & 7,2 & 2,1 \\
\hline 30,9 & 30,9 & 22,6 & 30,0 \\
\hline 6,9 & 3,3 & 7,1 & 4,2 \\
\hline 3,3 & 1,2 & 4,0 & 1,5 \\
\hline 4,9 & 38,1 & & 35,3 \\
\hline 29,5 & 34,6 & & 33,9 \\
\hline 31,6 & 13,5 & & 13,5 \\
\hline 17,9 & 7,3 & & 8,2 \\
\hline 16,1 & 6,5 & & 9,1 \\
\hline 4,5 & 36,5 & 4,0 & 35,1 \\
\hline 20,8 & 22,1 & 16,4 & 22,2 \\
\hline 35,4 & 21,5 & 29,4 & 21,8 \\
\hline 32,1 & 16,3 & 29,4 & 17,2 \\
\hline 7,2 & 3,6 & 20,9 & $\begin{array}{r}3,8 \\
\text { ues) }\end{array}$ \\
\hline
\end{tabular}


Table 1 (continued)

\section{YOUNG FIRMS}

\begin{tabular}{|c|c|c|}
\hline $\begin{array}{r}\begin{array}{r}\text { Entrepreneur-owner } \\
\text { firms }\end{array} \\
\end{array}$ & & $\begin{array}{r}\text { Pure owner } \\
\text { firms } \\
\end{array}$ \\
\hline Employees & Owners & Employees \\
\hline
\end{tabular}

ALL FIRMS

\begin{tabular}{|c|c|c|}
\hline $\begin{array}{r}\begin{array}{r}\text { Entrepreneur-owner } \\
\text { firms }\end{array} \\
\end{array}$ & & $\begin{array}{r}\text { Pure owner } \\
\text { firms }\end{array}$ \\
\hline Employees & Owners & Employees \\
\hline
\end{tabular}

\section{Gender}

Share of women

19,4

32,3

$$
21,9
$$

33,7

$$
15,0
$$$$
33,3
$$

19,0

33,5

No experience in another firm

$\begin{array}{rrrr}14,3 & 27,3 & 19,7 & 28,7 \\ 26,1 & 39,2 & 19,7 & 39,9 \\ 40,9 & 22,0 & 29,3 & 21,3 \\ 10,2 & 7,3 & 15,6 & 5,7 \\ 4,7 & 2,0 & 7,2 & 2,0 \\ 3,8 & 2,2 & 8,5 & 2,4\end{array}$

52,7
7,8
18,0
11,2
5,5
4,7

45,7

$\begin{array}{rrr}45,7 & 38,8 & 43,5 \\ 26,0 & 12,3 & 25,7 \\ 16,8 & 19,0 & 17,5 \\ 6,4 & 11,7 & 6,9 \\ 2,3 & 7,5 & 2,7 \\ 2,7 & 10,7 & 3,7\end{array}$

Performance of the previous employer $\mathrm{n} / \mathrm{a}$

1. Low productivity (quartiles)

2. Medium low productivity

3. Medium high productivity

$33,9 \quad 34$

$\begin{array}{ll}33,9 & 34,7 \\ 12,2 & 13,3\end{array}$

47,2

35,5

74,9

$50,9 \quad 66,9$

48,5

$17,4 \quad 21,6$

$9,5 \quad 13,6$

13,7

22,3

17,8

17,3

13,6

16,1

4,5

6,4

6,7

9,1

6,0

9,7

4. High productivity

18,8

13,1

15,9

12,5

7,6

16,3

17,0

$\begin{array}{lll}8,6 & 13,6\end{array}$


Table 2. Performance of young entrepreneur-owner firms and the role of owner and employee characteristics

Dependent variables

\section{Education}

Ref: Basic education

Non-technical vocational

Non-technical lower university

Non-technical higher university

Technical vocational

Technical lower university

Technical higher university

\section{$\underline{\text { Age (general experience) }}$}

Ref: $61+$ years

$<30$ years

$31-40$ years

$41-50$ years

$51-60$ years

Gender

Share of women

\begin{tabular}{l}
$\begin{array}{l}\text { Labor productivity } \\
\mathbf{2 0 0 9}\end{array}$ \\
\hline Owners Employees
\end{tabular}

Labor productivity

2013

Owners Employees
Survival 2009-2013

Owners Employees
Employment growth 2009-2013

Owners Employees

$\begin{array}{llllllll}0.0154 & 0.0492 & 0.0805^{*} & -0.0346 & 0.0757 & 0.166 & -0.00129 & -0.00709 \\ (0.0436) & (0.0560) & (0.0458) & (0.0579) & (0.119) & (0.149) & (0.0169) & (0.0189) \\ -0.0802 & 0.171 & -0.00722 & -0.125 & 0.337 & 0.616^{* *} & -0.0285 & 0.0147 \\ (0.0809) & (0.108) & (0.0804) & (0.149) & (0.259) & (0.311) & (0.0319) & (0.0399) \\ 0.134 * * & 0.0637 & 0.0798 & 0.0590 & 0.0764 & 1.004^{* * *} & 0.00929 & -0.0225 \\ (0.0626) & (0.128) & (0.0698) & (0.133) & (0.243) & (0.386) & (0.0310) & (0.0425) \\ 0.00541 & 0.0454 & 0.00667 & -0.0468 & 0.146 & 0.251 & -0.00975 & -0.0170 \\ (0.0397) & (0.0653) & (0.0501) & (0.0650) & (0.122) & (0.155) & (0.0157) & (0.0191) \\ 0.0373 & 0.0309 & 0.142^{*} & 0.0297 & 0.534^{* * *} & 0.403 & -0.0306 & 0.0614 * \\ (0.0633) & (0.0983) & (0.0863) & (0.0975) & (0.206) & (0.335) & (0.0361) & (0.0334) \\ 0.229 * * * & 0.110 & 0.190^{* *} & 0.0557 & 0.406 & 0.0536 & 0.0101 & 0.0640 \\ (0.0705) & (0.127) & (0.0794) & (0.216) & (0.255) & (0.408) & (0.0359) & (0.0492)\end{array}$

$\begin{array}{llllllll}0.156 & -0.174 * * & 0.00211 & 0.104 & 0.477 & 0.597 * & 0.0337 & 0.0322 \\ (0.125) & (0.0859) & (0.0843) & (0.142) & (0.317) & (0.308) & (0.0349) & (0.0349) \\ 0.132 & -0.0593 & 0.00569 & 0.140 & 0.482 & 0.608^{*} & 0.0203 & 0.0276 \\ (0.118) & (0.0893) & (0.0743) & (0.138) & (0.305) & (0.314) & (0.0324) & (0.0341) \\ 0.128 & -0.0647 & -0.0118 & 0.123 & 0.568^{*} & 0.640 * * & 0.0210 & -0.00610 \\ (0.118) & (0.0886) & (0.0769) & (0.144) & (0.306) & (0.317) & (0.0328) & (0.0342) \\ 0.0674 & -0.117 & 0.0473 & 0.0801 & 0.492 & 0.469 & 0.0157 & 0.00524 \\ (0.123) & (0.0977) & (0.0762) & (0.147) & (0.315) & (0.339) & (0.0328) & (0.0358) \\ & & & & & & & \\ -0.0236 & -0.127 * * & -0.0245 & -0.0648 & -0.0812 & 0.251^{*} & 0.00504 & 0.0117 \\ (0.0340) & (0.0527) & (0.0421) & (0.0575) & (0.118) & (0.134) & (0.0188) & (0.0170)\end{array}$

(continues) 
Table 2 (continued)

Dependent variables

\begin{tabular}{llllll}
$\begin{array}{l}\text { Labor productivity } \\
\text { 2009 }\end{array}$ & \multicolumn{2}{l}{$\begin{array}{l}\text { Labor productivity } \\
2013\end{array}$} & $\begin{array}{l}\text { Survival } \\
\text { 2009-2013 }\end{array}$ & $\begin{array}{l}\text { Employment growth } \\
\text { 2009-2013 }\end{array}$ \\
\hline Owners & Employees & Owners & Employees & Owners Employees & Owners Employees
\end{tabular}

\section{Previous experience}

Ref: $15+$ years

No experience in another firm

\begin{tabular}{llllllll}
0.0302 & $-0.439 * * *$ & -0.0766 & 0.0200 & $-0.111^{*}$ & $-0.160^{*}$ & 0.00922 & -0.0286 \\
$(0.0877)$ & $(0.0990)$ & $(0.0662)$ & $(0.165)$ & $(0.0569)$ & $(0.0817)$ & $(0.0240)$ & $(0.0368)$ \\
-0.0400 & $-0.279 * * *$ & -0.0981 & 0.140 & $-0.137 * *$ & $-0.138^{*}$ & 0.00139 & -0.0144 \\
$(0.0810)$ & $(0.0942)$ & $(0.0627)$ & $(0.155)$ & $(0.0537)$ & $(0.0792)$ & $(0.0226)$ & $(0.0347)$ \\
0.0143 & $-0.161^{*}$ & -0.0822 & 0.178 & -0.0814 & -0.114 & -0.00759 & -0.0178 \\
$(0.0788)$ & $(0.0948)$ & $(0.0628)$ & $(0.168)$ & $(0.0532)$ & $(0.0805)$ & $(0.0210)$ & $(0.0345)$ \\
0.0950 & -0.160 & -0.0717 & 0.213 & -0.0847 & -0.0321 & $0.0439^{*}$ & -0.0234 \\
$(0.0824)$ & $(0.109)$ & $(0.0686)$ & $(0.159)$ & $(0.0576)$ & $(0.0893)$ & $(0.0224)$ & $(0.0362)$ \\
0.0546 & -0.243 & -0.292 & 0.174 & -0.0403 & -0.00534 & -0.00388 & -0.0186 \\
$(0.105)$ & $(0.150)$ & $(0.180)$ & $(0.199)$ & $(0.0651)$ & $(0.114)$ & $(0.0283)$ & $(0.0479)$ \\
\hline
\end{tabular}

\section{Performance of the previous employer}

Ref: High productivity (quartile 4)

\begin{tabular}{|c|c|c|c|c|c|c|c|c|}
\hline $\mathrm{n} / \mathrm{a}$ & $\begin{array}{l}-0.150 \text { *** } \\
(0.0402)\end{array}$ & $\begin{array}{c}-0.0989^{*} \\
(0.0574)\end{array}$ & $\begin{array}{l}-0.125 * * \\
(0.0530)\end{array}$ & $\begin{array}{l}-0.133 * * \\
(0.0632)\end{array}$ & $\begin{array}{l}-0.0567 * * \\
(0.0267)\end{array}$ & $\begin{array}{l}-0.0312 \\
(0.0392)\end{array}$ & $\begin{array}{l}0.0250 \\
(0.0204)\end{array}$ & $\begin{array}{l}0.0144 \\
(0.0214)\end{array}$ \\
\hline 1. Low productivity & $\begin{array}{l}-0.109 * * \\
(0.0497)\end{array}$ & $\begin{array}{l}-0.239 * * * \\
(0.0735)\end{array}$ & $\begin{array}{l}-0.115^{*} \\
(0.0619)\end{array}$ & $\begin{array}{l}-0.152 * * \\
(0.0667)\end{array}$ & $\begin{array}{l}-0.0745^{* *} \\
(0.0311)\end{array}$ & $\begin{array}{l}-0.0857 * * \\
(0.0431)\end{array}$ & $\begin{array}{l}-0.0144 \\
(0.0263)\end{array}$ & $\begin{array}{l}-0.0119 \\
(0.0267)\end{array}$ \\
\hline 2. Medium low productivity & $\begin{array}{l}-0.116^{* * *} \\
(0.0428)\end{array}$ & $\begin{array}{l}-0.228 * * * \\
(0.0614)\end{array}$ & $\begin{array}{l}-0.122 \\
(0.0744)\end{array}$ & $\begin{array}{l}-0.252 * * * \\
(0.0651)\end{array}$ & $\begin{array}{l}-0.0004 \\
(0.0297)\end{array}$ & $\begin{array}{l}-0.0811^{* *} \\
(0.0395)\end{array}$ & $\begin{array}{l}0.00649 \\
(0.0245)\end{array}$ & $\begin{array}{l}0.00804 \\
(0.0246)\end{array}$ \\
\hline 3. Medium high productivity & $\begin{array}{l}-0.0286 \\
0.0492 \\
\end{array}$ & $\begin{array}{l}-0.192 * * * \\
(0.0627)\end{array}$ & $\begin{array}{l}-0.0770 \\
(0.0563)\end{array}$ & $\begin{array}{l}-0.131^{*} \\
(0.0776) \\
\end{array}$ & $\begin{array}{l}-0.0239 \\
(0.0289) \\
\end{array}$ & $\begin{array}{l}-0.00714 \\
(0.0415) \\
\end{array}$ & $\begin{array}{l}0.0109 \\
(0.0199)\end{array}$ & $\begin{array}{l}-0.0215 \\
(0.0238)\end{array}$ \\
\hline Number of observations & $\begin{array}{l}2,828 \\
0.236\end{array}$ & & $\begin{array}{l}2,051 \\
0.210\end{array}$ & & 3,031 & & $\begin{array}{l}2,081 \\
0.097\end{array}$ & \\
\hline Pseudo-R-squared & & & & & 0.0513 & & & \\
\hline
\end{tabular}


Table 3. Performance of young pure owner firms and the role of owner and employee characteristics

$\underline{\text { Dependent variables }}$

\section{Labor productivity}

2009

Owners Employees

\section{Labor productivity}

2013

\section{Education}

Ref: Basic education

Non-technical vocational

Non-technical lower university

Non-technical higher university

Technical vocational

Technical lower university

Technical higher university

\section{$\underline{\text { Age (general experience) }}$}

Ref: $61+$ years

$<30$ years

31-40 years

41-50 years

51-60 years

Gender

Share of women

(0.106) (0.196)

$\begin{array}{ll}-0.0384 & 0.0865 \\ (0.0445) & (0.0640) \\ -0.0247 & 0.174 \\ (0.0839) & (0.146) \\ -0.0888 & 0.367 * \\ (0.0814) & (0.193) \\ 0.0426 & 0.0551 \\ (0.0490) & (0.0624) \\ 0.00140 & -0.0541 \\ (0.0888) & (0.176) \\ 0.0916 & 0.218 \\ (0.0752) & (0.248)\end{array}$

0.0402

$-0.157^{*}$

$(0.0561) \quad(0.0921)$

$-0.0960 \quad 0.202$

(0.116) (0.183)

$-0.123 \quad 0.414$

(0.105) (0.254)

0.121

$-0.0122$

$(0.0741) \quad(0.0725)$

0.0881

$-0.146$

$(0.102) \quad(0.244)$

$-0.0139-0.0880$

(0.118) (0.421)

0.0760

(0.132)

0.0636

(0.258)

$-0.224$

(0.208)

0.00114

(0.143)

0.0939

$(0.222)$

0.185

(0.289)

0.125

0.0182

(0.0210)

$-0.0206$

$(0.0325)-(0.0506)$

(0.341)

0.0296

(0.389)

0.188

(0.168)

$0.953 * * *$

(0.368)

0.598

(0.502)

$\begin{array}{ll}0.0473 & -0.0747 \\ (0.0816) & (0.132) \\ 0.0402 & 0.0667 \\ (0.0668) & (0.129) \\ 0.0167 & -0.113 \\ (0.0654) & (0.135) \\ 0.0172 & 0.0288 \\ (0.0711) & (0.129)\end{array}$

$0.305 * * \quad-0.0448$

0.0517

(0.228)

$1.027 * * *$

(0.364)

$0.754 * *$

$0.207 * * \quad 0.0822$

0.198

(0.104) (0.193)

$0.200 *$

$-0.199$

(0.194)

(0.370)

0.235

0.353

$0.212 *$

0.167

(0.189)

(0.368)

(0.110)

(0.194)

$0.847^{*}$

(0.198) (0.384)

$-0.0154$

(0.0330) (0.0664)

$-0.0185 \quad-0.000166$

(0.0310) (0.0306)

$0.00106 \quad-0.0364$

(0.0400) (0.0713)

$-0.0523 \quad 0.0829$

$(0.0521) \quad(0.0854)$

$\begin{array}{ll}0.0481 & 0.165 * * * \\ (0.0356) & (0.0563) \\ 0.0157 & 0.113 * * \\ (0.0292) & (0.0571) \\ 0.000432 & 0.114 * \\ (0.0288) & (0.0589) \\ -0.000670 & 0.0669 \\ (0.0287) & (0.0576)\end{array}$

$-0.0457-0.110^{*}$

$0.0672-0.150 *$

$-0.166$

0.0280

$-0.0155 \quad-0.00738$

(0.0424) (0.0611)
(0.0537) (0.0771)

(0.120)

$(0.150)$ $\begin{array}{rr}(0.0183) & (0.0289) \\ \text { (continues) }\end{array}$ 
Table 3 (continued)

\begin{tabular}{|c|c|c|c|c|c|c|c|c|}
\hline \multirow[t]{2}{*}{$\underline{\text { Dependent variables }}$} & \multicolumn{2}{|c|}{$\begin{array}{l}\text { Labor productivity } \\
2009\end{array}$} & \multicolumn{2}{|c|}{$\begin{array}{l}\text { Labor productivity } \\
2013\end{array}$} & \multicolumn{2}{|l|}{$\begin{array}{l}\text { Survival } \\
2009-2013 \\
\end{array}$} & \multicolumn{2}{|c|}{$\begin{array}{l}\text { Employment growth } \\
2009-2013\end{array}$} \\
\hline & Owners & Employees & Owners & Employees & Owners & Employees & Owners & Employees \\
\hline \multicolumn{9}{|l|}{ Previous experience } \\
\hline \multicolumn{9}{|l|}{ Ref: $15+$ years } \\
\hline No experience in another firm & $\begin{array}{l}-0.0575 \\
(0.0658)\end{array}$ & $\begin{array}{l}-0.257^{*} \\
(0.154)\end{array}$ & $\begin{array}{l}0.0476 \\
(0.0945)\end{array}$ & $\begin{array}{l}-0.149 \\
(0.219)\end{array}$ & $\begin{array}{l}-0.151 * * * \\
(0.0445)\end{array}$ & $\begin{array}{l}-0.192 * \\
(0.0977)\end{array}$ & $\begin{array}{l}-0.00823 \\
(0.0281)\end{array}$ & $\begin{array}{l}-0.108^{*} \\
(0.0558)\end{array}$ \\
\hline$<1$ year & $\begin{array}{l}-0.0532 \\
(0.0668)\end{array}$ & $\begin{array}{l}-0.133 \\
(0.145)\end{array}$ & $\begin{array}{l}0.0561 \\
(0.0863)\end{array}$ & $\begin{array}{l}0.0706 \\
(0.209)\end{array}$ & $\begin{array}{l}-0.204 * * * \\
(0.0433)\end{array}$ & $\begin{array}{l}-0.247 * * * \\
(0.0944)\end{array}$ & $\begin{array}{l}0.0173 \\
(0.0299)\end{array}$ & $\begin{array}{l}-0.144 * * * \\
(0.0543)\end{array}$ \\
\hline $1-5$ years & $\begin{array}{l}-0.0898 \\
(0.0620)\end{array}$ & $\begin{array}{l}-0.0393 \\
(0.148)\end{array}$ & $\begin{array}{l}0.00205 \\
(0.0814)\end{array}$ & $\begin{array}{l}0.0918 \\
(0.203)\end{array}$ & $\begin{array}{l}-0.125 * * * \\
(0.0419)\end{array}$ & $\begin{array}{l}-0.202 * * \\
(0.0958)\end{array}$ & $\begin{array}{l}-0.00464 \\
(0.0214)\end{array}$ & $\begin{array}{l}-0.150 * * * \\
(0.0539)\end{array}$ \\
\hline $5-10$ years & $\begin{array}{l}-0.0229 \\
(0.0656)\end{array}$ & $\begin{array}{l}-0.0433 \\
(0.160)\end{array}$ & $\begin{array}{l}0.0259 \\
(0.0821)\end{array}$ & $\begin{array}{l}0.0821 \\
(0.227)\end{array}$ & $\begin{array}{l}-0.191 * * * \\
(0.0441)\end{array}$ & $\begin{array}{l}-0.0337 \\
(0.106)\end{array}$ & $\begin{array}{l}-0.00529 \\
(0.0229)\end{array}$ & $\begin{array}{l}-0.149 * * \\
(0.0601)\end{array}$ \\
\hline $10-15$ years & $\begin{array}{l}0.145^{* *} \\
(0.0715)\end{array}$ & $\begin{array}{l}0.168 \\
(0.195)\end{array}$ & $\begin{array}{l}0.179 \\
(0.117)\end{array}$ & $\begin{array}{l}0.462 \\
(0.303)\end{array}$ & $\begin{array}{l}-0.0779 \\
(0.0518)\end{array}$ & $\begin{array}{l}-0.242 * * \\
(0.117)\end{array}$ & $\begin{array}{l}-0.0402 \\
(0.0342)\end{array}$ & $\begin{array}{l}-0.144 * \\
(0.0770)\end{array}$ \\
\hline \multicolumn{9}{|c|}{ Performance of the previous employer } \\
\hline \multicolumn{9}{|c|}{ Ref: High productivity (quartile 4) } \\
\hline $\mathrm{n} / \mathrm{a}$ & $\begin{array}{l}0.0138 \\
(0.0513)\end{array}$ & $\begin{array}{l}-0.209 * * * \\
(0.0762)\end{array}$ & $\begin{array}{l}0.0553 \\
(0.0736)\end{array}$ & $\begin{array}{l}-0.284 * * \\
(0.143)\end{array}$ & $\begin{array}{l}0.0115 \\
(0.0313)\end{array}$ & $\begin{array}{l}-0.0426 \\
(0.0469)\end{array}$ & $\begin{array}{l}-0.0280 \\
(0.0208)\end{array}$ & $\begin{array}{l}0.00705 \\
(0.0523)\end{array}$ \\
\hline 1. Low productivity & $\begin{array}{l}-0.0331 \\
(0.0641)\end{array}$ & $\begin{array}{l}-0.383 * * * \\
(0.0912)\end{array}$ & $\begin{array}{l}-0.0234 \\
(0.0827)\end{array}$ & $\begin{array}{l}-0.414 * * * \\
(0.150)\end{array}$ & $\begin{array}{l}-0.0846^{* *} \\
(0.0415)\end{array}$ & $\begin{array}{l}-0.133 * * * \\
(0.0500)\end{array}$ & $\begin{array}{l}-0.0121 \\
(0.0230)\end{array}$ & $\begin{array}{l}0.0119 \\
(0.0560)\end{array}$ \\
\hline 2. Medium low productivity & $\begin{array}{l}0.0890 \\
(0.0558)\end{array}$ & $\begin{array}{l}-0.365^{* * * *} \\
(0.0809)\end{array}$ & $\begin{array}{l}0.0882 \\
(0.0731)\end{array}$ & $\begin{array}{l}-0.288 * * \\
(0.145)\end{array}$ & $\begin{array}{l}-0.0145 \\
(0.0376)\end{array}$ & $\begin{array}{l}0.0114 \\
(0.0486)\end{array}$ & $\begin{array}{l}-0.00189 \\
(0.0274)\end{array}$ & $\begin{array}{l}0.0845 \\
(0.0568)\end{array}$ \\
\hline 3. Medium high productivity & $\begin{array}{l}0.0327 \\
0.0865\end{array}$ & $\begin{array}{l}-0.214 * * \\
(0.0883)\end{array}$ & $\begin{array}{l}-0.00420 \\
(0.0902)\end{array}$ & $\begin{array}{l}-0.119 \\
(0.141)\end{array}$ & $\begin{array}{l}-0.0178 \\
(0.0374)\end{array}$ & $\begin{array}{l}-0.0185 \\
(0.0505)\end{array}$ & $\begin{array}{l}-0.0112 \\
(0.0259)\end{array}$ & $\begin{array}{l}0.0462 \\
(0.0539)\end{array}$ \\
\hline Number of observations & $\begin{array}{l}1,885 \\
0.233\end{array}$ & & $\begin{array}{l}1,298 \\
0.276\end{array}$ & & 2,279 & & $0.174^{1,303}$ & \\
\hline Pseudo-R-squared & & & & & 0.0757 & & & \\
\hline
\end{tabular}


Figure 1.a Estimated cohort effects on productivity in 2009 and 2013

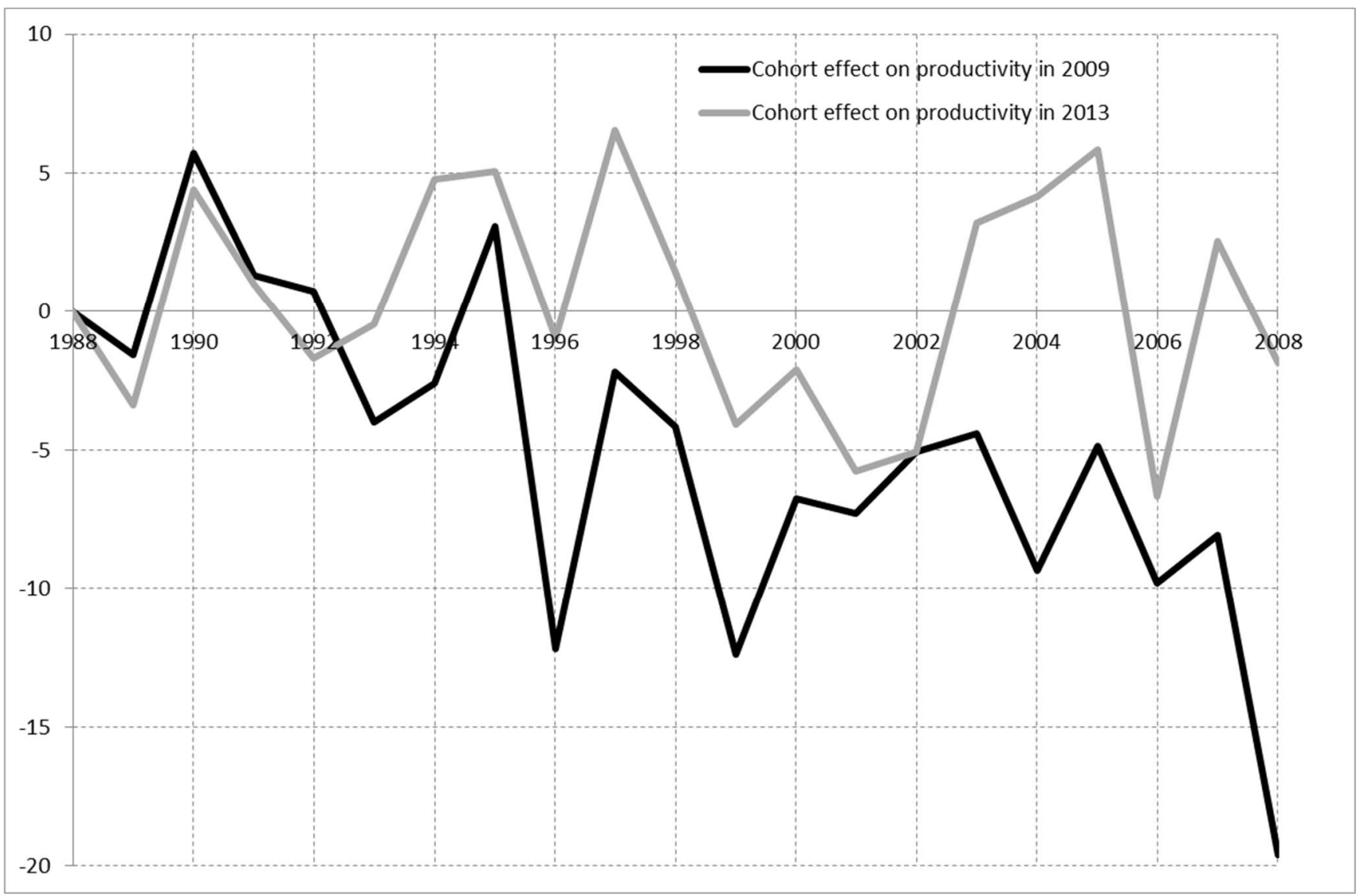

Figure 1.b Estimated cohort effects on survival probability and employment growth in years 2009-2013

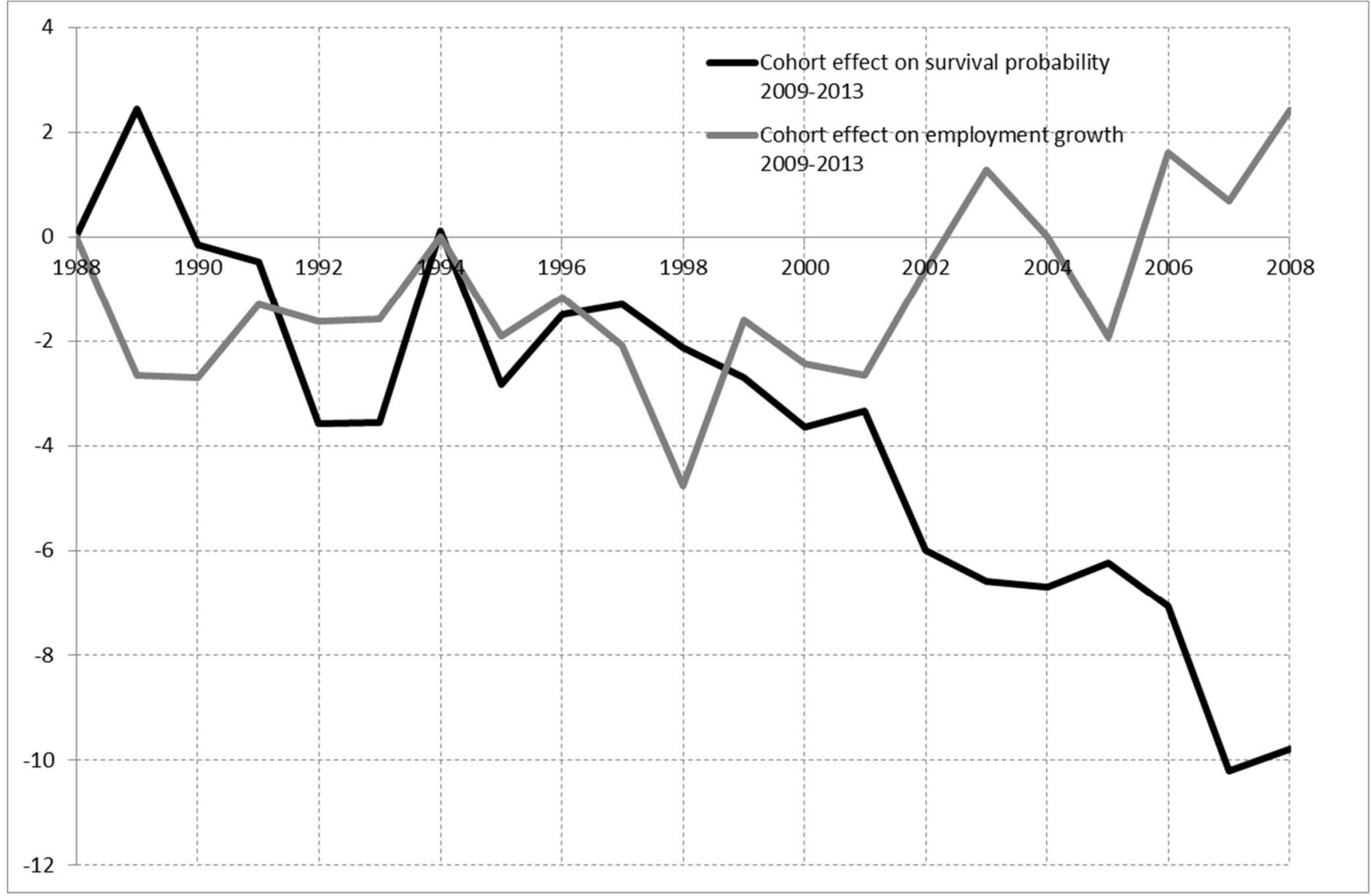


25

Figure 2. Estimated effect of birth year on labor productivity level of firm in 2009 and excess job reallocation rate (\%) in sector

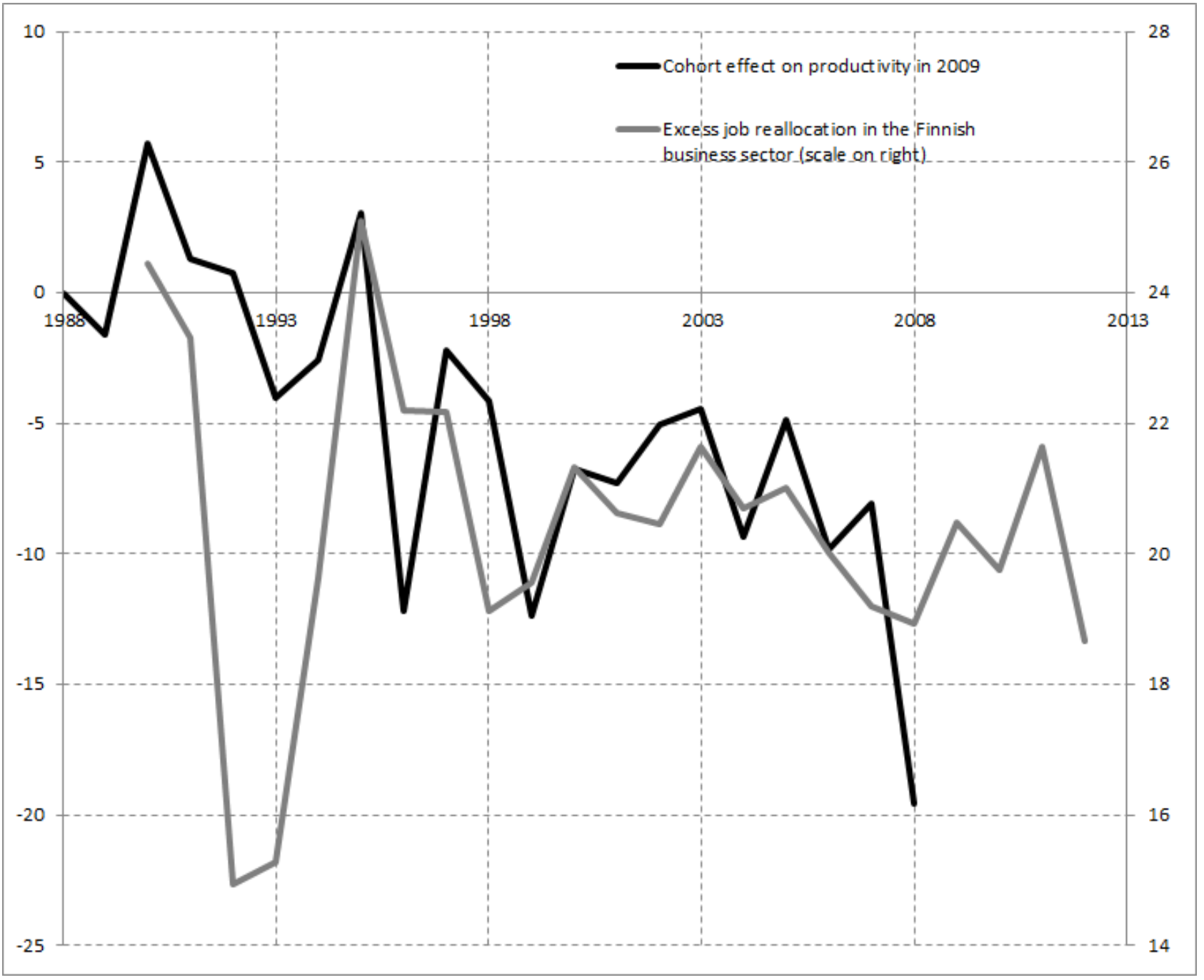


Table 4. Descriptive statistics: regression estimations of the relationship between birth year effects and "creative destruction"

\section{Explanatory variable}

A. Entrepreneur-owner firms

\section{Excess job reallocation}

$$
\begin{array}{r}
\text { Coefficients } \\
P \text {-value }
\end{array}
$$

Recession year 1992-93

$$
\begin{array}{r}
\text { Coefficients } \\
\text { P-value }
\end{array}
$$

Detrended

Adjusted R Square

Observations

B. Pure owner firms

\section{Excess job reallocation}

$\begin{array}{rr}\text { Coefficients } & 1,87 \\ P \text {-value } & 3,8 \%\end{array}$

Recession year 1992-93

$$
2,41
$$

$-0,37$

0,11

$0,1 \%$

18,74

$-6,29$

$0,2 \%$

yes

$88,4 \%$

19
$47,1 \%$

19
$70,4 \%$

1,62

$52,9 \%$

yes

$19,9 \%$

19
0,44

$44,4 \%$

$67,2 \%$
Survival Employment

2009-2013 growth 2009-2013

Coefficients

16,06

3,03

$-3,25$

$P$-value

$3,0 \%$

Detrended

no (insignificant)

Adjusted R Square

$19,0 \%$

Observations

19

$54,8 \%$

$49,7 \%$

yes

yes

$48,2 \%$

$-9,5 \%$

19

19

Note: Table summarizes 6 time-series estimations in which the dependent variable is the point estimate of birth year effect and the explanatory variable is an indicator of economic conditions, measured by a "creative destruction" indicator. 
Figure 3. Birth year effect in firm-level regressions and predicted effect on basis of excess job reallocation (\%)

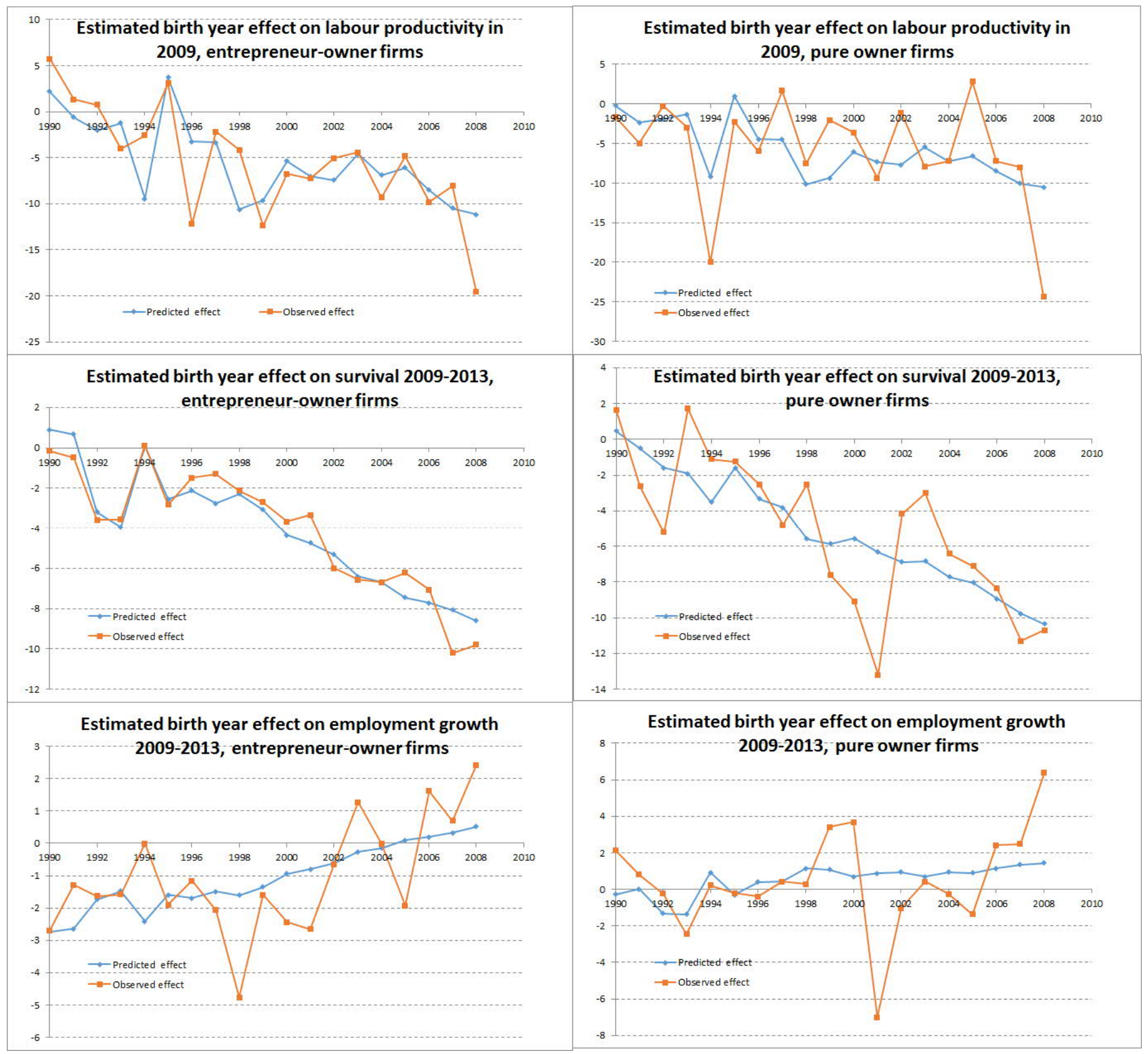


Appendix: Table A1. Summary statistics by sector: all entrepreneur-owner firms

\begin{tabular}{|c|c|c|c|c|c|c|c|c|c|}
\hline \multirow[b]{2}{*}{ Sector } & \multirow[b]{2}{*}{$\begin{array}{r}\text { No. } \\
\text { of } \\
\text { firms }\end{array}$} & \multirow[b]{2}{*}{$\begin{array}{r}\text { Mean } \\
\text { size }\end{array}$} & \multirow[b]{2}{*}{$\begin{array}{l}\text { Survival } \\
\text { probability }\end{array}$} & \multicolumn{3}{|c|}{ Owners } & \multicolumn{3}{|c|}{ Employees } \\
\hline & & & & $\begin{array}{l}\text { Share of } \\
\text { highly } \\
\text { educated }\end{array}$ & $\begin{array}{l}\text { Share of } \\
\text { technical } \\
\text { education }\end{array}$ & $\begin{array}{l}\text { Share of } \\
\text { women }\end{array}$ & $\begin{array}{l}\text { Share of } \\
\text { highly } \\
\text { educated }\end{array}$ & $\begin{array}{l}\text { Share of } \\
\text { technical } \\
\text { education }\end{array}$ & $\begin{array}{l}\text { Share of } \\
\text { women }\end{array}$ \\
\hline Accommodation and food service activities & 1087 & 6.4 & 72.8 & 6.0 & 9.1 & 37.1 & 4.5 & 5.9 & 66.8 \\
\hline $\begin{array}{l}\text { Basic metals and fabricated metal products } \\
\text { (excluding machinery and equipment) }\end{array}$ & 750 & 9.6 & 84.0 & 17.2 & 70.3 & 5.1 & 6.5 & 60.5 & 12.8 \\
\hline Construction & 3961 & 7.0 & 78.5 & 9.9 & 62.3 & 4.3 & 4.3 & 54.6 & 9.6 \\
\hline $\begin{array}{l}\text { Chemical, rubber, plastics, fuel products and } \\
\text { other non-metallic mineral products }\end{array}$ & 209 & 10.6 & 82.8 & 18.7 & 48.3 & 8.6 & 10.5 & 42.5 & 30.4 \\
\hline Food products, beverages and tobacco & 166 & 12.0 & 79.5 & 12.7 & 22.3 & 27.1 & 3.3 & 27.8 & 56.8 \\
\hline $\begin{array}{l}\text { Furniture; other manufacturing; repair and } \\
\text { installation of machinery and equipment }\end{array}$ & 532 & 7.6 & 82,0 & 12.2 & 49.2 & 6.2 & 7.0 & 50.9 & 24.3 \\
\hline IT and other information services & 374 & 4.7 & 77.8 & 47.1 & 47.3 & 6.4 & 42.2 & 42.4 & 23.1 \\
\hline Machinery and equipment & 341 & 10.3 & 82.7 & 26.7 & 66.6 & 5.6 & 14.5 & 61.6 & 20.6 \\
\hline $\begin{array}{l}\text { Professional, scientific and technical } \\
\text { activities; administrative and support } \\
\text { activities }\end{array}$ & 3147 & 6.1 & 78.0 & 39.0 & 36.6 & 25.1 & 21.5 & 26.5 & 49.0 \\
\hline $\begin{array}{l}\text { Publishing, audiovisual and broadcasting } \\
\text { activities }\end{array}$ & 161 & 6.0 & 68.3 & 21.1 & 10.6 & 11.8 & 22.9 & 16.8 & 47.1 \\
\hline Real estate activities & 347 & 4.2 & 78.1 & 18.7 & 16.7 & 27.4 & 15.3 & 16.4 & 55.5 \\
\hline Telecommunications & 20 & 3.6 & 85.0 & 35.0 & 25.0 & 10.0 & 37.7 & 40.6 & 21.7 \\
\hline $\begin{array}{l}\text { Textiles, wearing apparel, leather and related } \\
\text { products }\end{array}$ & 135 & 7.6 & 86.7 & 8.9 & 27.4 & 28.1 & 8.0 & 37.1 & 68.4 \\
\hline Transport equipment & 67 & 21.5 & 76.1 & 13.4 & 59.7 & 3.0 & 6.5 & 53.6 & 12.7 \\
\hline Transportation and storage & 1816 & 6.1 & 84,7 & 3.7 & 36.3 & 4.8 & 2.8 & 29.5 & 11.1 \\
\hline $\begin{array}{l}\text { Wholesale and retail trade, repair of motor } \\
\text { vehicles and motorcycles }\end{array}$ & 4303 & 6.2 & 79.8 & 13.4 & 29.6 & 19.7 & 9.2 & 23.6 & 48.0 \\
\hline Wood and paper products and printing & 382 & 8.9 & 75.7 & 13.9 & 45.5 & 8.1 & 9.0 & 43.2 & 24.5 \\
\hline
\end{tabular}


Table A2. Summary statistics by sector, all pure owner firms

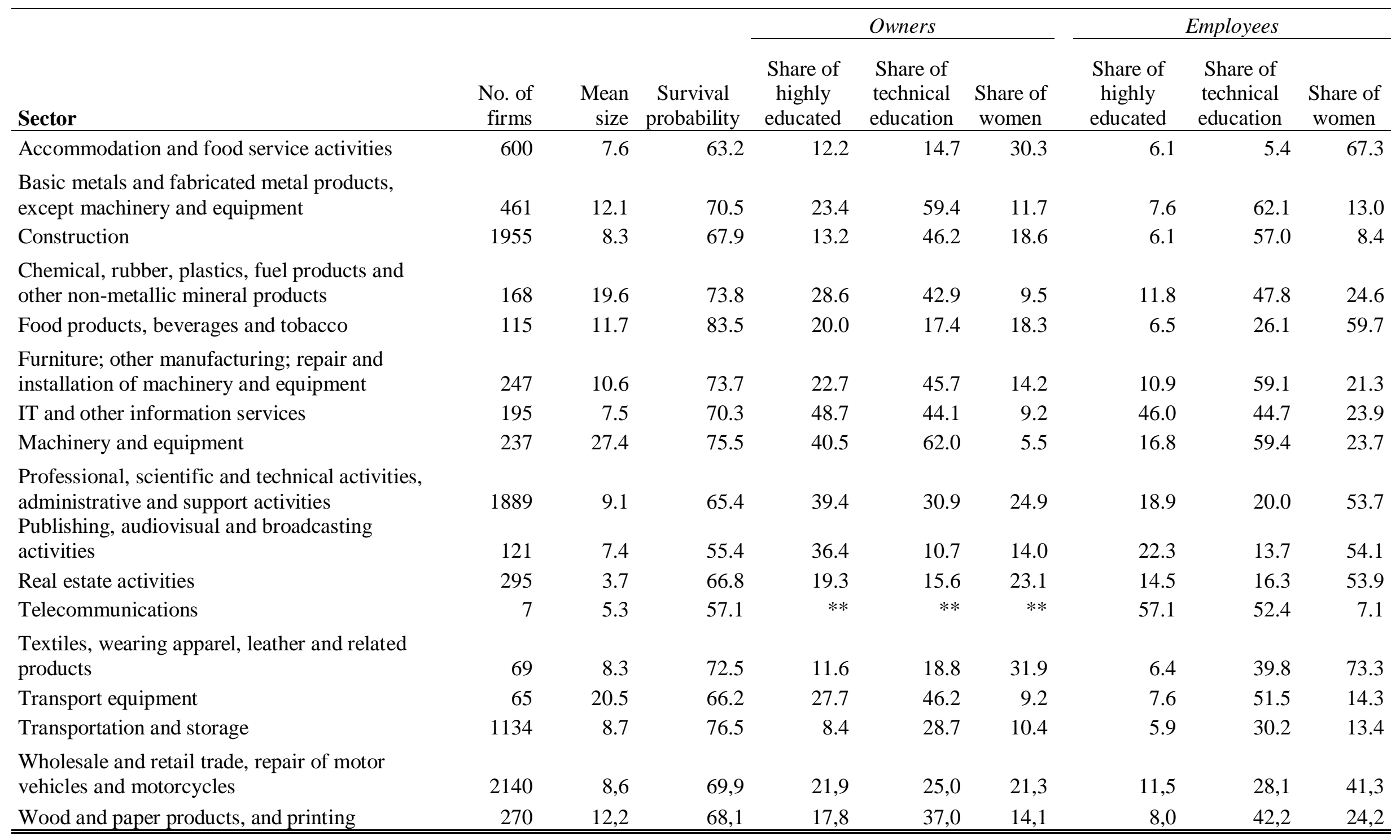

**Share cannot be revealed for reasons of confidentiality. 
Table A3. Performance of all entrepreneur-owner firms and the role of owner and employee characteristics

\begin{tabular}{|c|c|c|c|c|c|c|c|c|}
\hline \multirow[t]{2}{*}{ Dependent variables } & \multicolumn{2}{|c|}{$\begin{array}{l}\text { Labor productivity } \\
2009\end{array}$} & \multicolumn{2}{|c|}{$\begin{array}{l}\text { Labor productivity } \\
2013\end{array}$} & \multicolumn{2}{|c|}{$\begin{array}{l}\text { Survival } \\
2009-2013 \\
\end{array}$} & \multicolumn{2}{|c|}{$\begin{array}{l}\text { Employment growth } \\
2009-2013\end{array}$} \\
\hline & Owners & Employees & Owners & Employees & Owners & Employees & Owners & Employees \\
\hline \multicolumn{9}{|l|}{$\underline{\text { Education }}$} \\
\hline \multicolumn{9}{|l|}{$\overline{\text { Ref: Basic education }}$} \\
\hline Non-technical vocational & $\begin{array}{l}0.0108 \\
(0.0168)\end{array}$ & $\begin{array}{l}0.0356 \\
(0.0243)\end{array}$ & $\begin{array}{l}-0.00268 \\
(0.0237)\end{array}$ & $\begin{array}{l}0.0283 \\
(0.0264)\end{array}$ & $\begin{array}{l}0.00962 \\
(0.00880)\end{array}$ & $\begin{array}{l}0.0249 * * \\
(0.0115)\end{array}$ & $\begin{array}{l}-0.00269 \\
(0.00888)\end{array}$ & $\begin{array}{l}0.00491 \\
(0.0100)\end{array}$ \\
\hline Non-technical polytechnic & $\begin{array}{l}0.0815^{*} \\
(0.0495)\end{array}$ & $\begin{array}{l}0.215^{* * * *} \\
(0.0457)\end{array}$ & $\begin{array}{l}0.0389 \\
(0.0570)\end{array}$ & $\begin{array}{l}0.0588 \\
(0.0618)\end{array}$ & $\begin{array}{l}0.0170 \\
(0.0199)\end{array}$ & $\begin{array}{l}0.0608^{* *} \\
(0.0250)\end{array}$ & $\begin{array}{l}0.0356^{*} \\
(0.0184)\end{array}$ & $\begin{array}{l}0.0379^{*} \\
(0.0204)\end{array}$ \\
\hline Non-technical higher university & $\begin{array}{l}0.0787 * * \\
(0.0401)\end{array}$ & $\begin{array}{l}0.274 * * * \\
(0.0591)\end{array}$ & $\begin{array}{l}-0.0150 \\
(0.0388)\end{array}$ & $\begin{array}{l}0.406 * * * \\
(0.0672)\end{array}$ & $\begin{array}{l}-0.0105 \\
(0.0180)\end{array}$ & $\begin{array}{l}0.110 * * * \\
(0.0307)\end{array}$ & $\begin{array}{l}-0.00361 \\
(0.0159)\end{array}$ & $\begin{array}{l}0.0215 \\
(0.0190)\end{array}$ \\
\hline Technical vocational & $\begin{array}{l}0.0288^{*} \\
(0.0157)\end{array}$ & $\begin{array}{l}-0.0119 \\
(0.0266)\end{array}$ & $\begin{array}{l}-0.00210 \\
(0.0205)\end{array}$ & $\begin{array}{l}0.0181 \\
(0.0257)\end{array}$ & $\begin{array}{l}0.00984 \\
(0.00856)\end{array}$ & $\begin{array}{l}0.0233^{*} \\
(0.0121)\end{array}$ & $\begin{array}{l}0.00409 \\
(0.00652)\end{array}$ & $\begin{array}{l}0.00767 \\
(0.0105)\end{array}$ \\
\hline Technical polytechnic & $\begin{array}{l}0.00239 \\
(0.0368)\end{array}$ & $\begin{array}{l}0.0851 \\
(0.0708)\end{array}$ & $\begin{array}{l}0.0364 \\
(0.0276)\end{array}$ & $\begin{array}{l}0.250 * * * \\
(0.0544)\end{array}$ & $\begin{array}{l}0.0338 * * \\
(0.0145)\end{array}$ & $\begin{array}{l}0.0288 \\
(0.0263)\end{array}$ & $\begin{array}{l}0.00626 \\
(0.0107)\end{array}$ & $\begin{array}{l}0.0357^{*} \\
(0.0195)\end{array}$ \\
\hline Technical higher university & $\begin{array}{l}0.111 * * * \\
(0.0411)\end{array}$ & $\begin{array}{l}0.138 \\
(0.123)\end{array}$ & $\begin{array}{l}0.00818 \\
(0.0505)\end{array}$ & $\begin{array}{l}0.262 * * \\
(0.102)\end{array}$ & $\begin{array}{l}0.0291 \\
(0.0205)\end{array}$ & $\begin{array}{l}0.0797 * \\
(0.0425)\end{array}$ & $\begin{array}{l}0.00815 \\
(0.0149)\end{array}$ & $\begin{array}{l}0.0299 \\
(0.0236)\end{array}$ \\
\hline
\end{tabular}


Table A3 (continued)

Dependent variables

\section{Experience in the firm}

Ref: $15+$ years

$<1$ year

$1-5$ years

5-10 years

10-15 years

\section{Age (general experience)}

Ref: $61+$ years

$<30$ years

31-40 years

$41-50$ years

51-60 years

\section{Gender}

Share of women

\section{Labor productivity \\ 2009}

$\begin{array}{ll}-0.0435 & -0.0233 \\ (0.0321) & (0.0501) \\ -0.00871 & 0.0585 \\ (0.0207) & (0.0464) \\ 0.0137 & -0.0204 \\ (0.0208) & (0.0527) \\ 0.00297 & -0.0532 \\ (0.0237) & (0.0533)\end{array}$

$-0.0178$

$\begin{array}{ll}(0.0371) & (0.0394) \\ 0.0131 & 0.0517\end{array}$

$\begin{array}{ll}(0.0279) \quad(0.0402) \\ -0.0136 & 0.0399\end{array}$

$\begin{array}{ll}-0.0136 & 0.0399\end{array}$

$(0.0256)$

0.00166

$(0.0389)$

(0.0273)

(0.0398)

$-0.0867 * * * \quad-0.176^{* * *}$

(0.0321)

(0.0223)
Labor productivity

2013

$\begin{array}{ll}0.00350 & -0.127 * * * \\ (0.0378) & (0.0447) \\ 0.0111 & -0.0751^{*} \\ (0.0199) & (0.0447) \\ -0.0179 & -0.119 * * \\ (0.0191) & (0.0503) \\ -0.0281 & 0.00223 \\ (0.0222) & (0.0696)\end{array}$

$0.0275 \quad 0.0491$

$(0.0358) \quad(0.0566)$

$0.0504 * 0.103 *$

$\begin{array}{ll}(0.0289) & (0.0561)\end{array}$

$0.0217 \quad 0.0901$

$\begin{array}{ll}0.0259) \quad(0.0578) & 0.0217\end{array}$

$0.0305 \quad 0.00814$

$(0.0264) \quad(0.0555)$

$-0.0405^{*}-0.145^{* * *}$

(0.0217) (0.0254)
Survival

2009-2013

$\begin{array}{ll}-0.0798^{* * *} & -0.0253 \\ (0.0161) & (0.0235) \\ -0.0477 * * * & 0.00656 \\ (0.0114) & (0.0247) \\ -0.0260^{* *} & -0.0187 \\ (0.0109) & (0.0265) \\ -0.0228^{*} & -0.0780^{* *} \\ (0.0117) & (0.0327)\end{array}$

$0.0218 \quad 0.0392 * *$

$0.0170) \quad(0.0162)$
$0.0140 *$

$-0.0140 * \quad 0.0453^{* * * *}$

$(0.00796) \quad(0.0158)$

$-0.00916 \quad 0.0300 *$

$\begin{array}{ll}(0.00795) & (0.0158)\end{array}$

$-0.0207 * * \quad-0.00584$

$(0.00954) \quad(0.0227)$

$\begin{array}{llll}0.109 * * * & 0.0694 * * * & 0.0206 & 0.0311 * * \\ (0.0174) & (0.0196) & (0.0175) & (0.0155) \\ 0.123 * * * & 0.0616 * * * & 0.0229 & 0.0337 * * \\ (0.0125) & (0.0203) & (0.0172) & (0.0135) \\ 0.136 * * * & 0.0598 * * * & 0.0165 & 0.0211 \\ (0.0116) & (0.0202) & (0.0134) & (0.0132) \\ 0.0894 * * * & 0.0282 & 0.00396 & 0.00399 \\ (0.0112) & (0.0203) & (0.0131) & (0.0133)\end{array}$

$-0.00894-0.0228 * *$

(0.00898)

\section{$-0.00671 \quad 0.00146$}

$(0.0148) \quad(0.00964)$ 
Table A3 (continued)

Dependent variables

\section{Previous experience}

Ref: $15+$ years

No experience in another firm

$<1$ year

$1-5$ years

5-10 years

$10-15$ years

\section{Labor productivity}

2009

$\begin{array}{ll}-0.0211 & -0.0532 \\ (0.0262) & (0.0533) \\ -0.0341 & -0.0344 \\ (0.0304) & (0.0506) \\ -0.00659 & 0.0355 \\ (0.0289) & (0.0526) \\ 0.0174 & -0.00724 \\ (0.0300) & (0.0595) \\ 0.0134 & -0.0149 \\ (0.0369) & (0.0691)\end{array}$

Labor productivity

2013

$\begin{array}{ll}0.00629 & 0.00223 \\ (0.0311) & (0.0696) \\ -0.00961 & 0.0283 \\ (0.0373) & (0.0688) \\ -0.0246 & 0.0691 \\ (0.0392) & (0.0718) \\ 0.0440 & 0.116 \\ (0.0346) & (0.0735) \\ -0.00555 & 0.179 * * \\ (0.0450) & (0.0842)\end{array}$

Survival

2009-2013

$\begin{array}{ll}-0.00641 & -0.0780 * * \\ (0.0166) & (0.0327) \\ -0.0438 * * & -0.0868 * * * \\ (0.0188) & (0.0320) \\ -0.00799 & -0.0490 \\ (0.0174) & (0.0326) \\ 0.00662 & -0.00447 \\ (0.0185) & (0.0358) \\ 0.0120 & 0.0182 \\ (0.0204) & (0.0466)\end{array}$

Employment growth 2009-2013

$\begin{array}{ll}-0.00155 & -0.00584 \\ (0.0121) & (0.0227) \\ 0.0155 & -0.00479 \\ (0.0178) & (0.0235) \\ -0.0115 & 0.00171 \\ (0.0155) & (0.0223) \\ 0.01000 & -0.00560 \\ (0.0157) & (0.0221) \\ -0.0152 & -0.0243 \\ (0.0163) & (0.0247)\end{array}$

\section{Performance of previous employer}

Ref: High productivity (quartile 4)

$\mathrm{n} / \mathrm{a}$

$\begin{array}{llll}-0.0341 & -0.238 * * * & 0.0249 & -0.136 * * * \\ (0.0229) & (0.0357) & (0.0330) & (0.0408) \\ -0.0971 * * * & -0.340 * * * & -0.0371 & -0.221 * * * \\ (0.0331) & (0.0460) & (0.0455) & (0.0501) \\ -0.0636 * & -0.276 * * * & -0.0205 & -0.151 * * * \\ (0.0337) & (0.0332) & (0.0404) & (0.0412) \\ -0.0136 & -0.181 * * * & -0.0659 * & -0.111 * * \\ (0.0247) & (0.0318) & (0.0368) & (0.0443) \\ 16724 & & 13605 & \\ 0.219 & & 0.168 & \end{array}$

$-0.0369 * * *$

$-0.00658$

(0.0133)

(0.0178)

$-0.0627 * * * \quad-0.0389 * *$

$-0.0107-0.0164$

$(0.0134) \quad(0.0165)$

$-0.00255-0.0164$

(0.0170) (0.0198)

$-0.0290 * \quad-0.0434 * *$

$(0.0217) \quad(0.0161)$

$\begin{array}{ll}-0.00351 & -0.00722\end{array}$

(0.0161) (0.0178)

$(0.0163) \quad(0.0147)$
-0.00983

$-0.0142$

$-0.00983-0.0177$

(0.0159)

(0.0186)

(0.0153)

(0.0146)
13833

0.088
R-squared

0.0536 
Table A4. Performance of all pure owner firms and the role of owner and employee characteristics

\begin{tabular}{|c|c|c|c|c|c|c|c|c|}
\hline \multirow[t]{2}{*}{ Dependent variables } & \multicolumn{2}{|c|}{$\begin{array}{l}\text { Labor productivity } \\
2009\end{array}$} & \multicolumn{2}{|c|}{$\begin{array}{l}\text { Labor productivity } \\
2013\end{array}$} & \multicolumn{2}{|c|}{$\begin{array}{l}\text { Survival } \\
2009-2013 \\
\end{array}$} & \multicolumn{2}{|c|}{$\begin{array}{l}\text { Employment growth } \\
2009-2013\end{array}$} \\
\hline & Owners & Employees & Owners & Employees & Owners & Employees & Owners & Employees \\
\hline \multicolumn{9}{|l|}{ Education } \\
\hline \multicolumn{9}{|l|}{ Ref: Basic education } \\
\hline \multirow[t]{2}{*}{ Non-technical vocational } & -0.00711 & $0.130 * * *$ & 0.0360 & $0.0952 *$ & 0.00712 & $0.0608 * * *$ & $0.0187 * *$ & -0.0226 \\
\hline & $(0.0273)$ & $(0.0450)$ & $(0.0525)$ & $(0.0490)$ & $(0.0131)$ & $(0.0182)$ & $(0.00939)$ & $(0.0148)$ \\
\hline \multirow[t]{2}{*}{ Non-technical polytechnic } & -0.0758 & 0.109 & 0.0496 & $0.310 * * *$ & 0.0255 & $0.0741 * *$ & 0.0233 & $-0.0836 * *$ \\
\hline & $(0.0598)$ & $(0.0974)$ & $(0.0755)$ & $(0.112)$ & $(0.0248)$ & $(0.0367)$ & $(0.0173)$ & $(0.0334)$ \\
\hline \multirow[t]{2}{*}{ Non-technical higher university } & -0.000291 & $0.401 * * *$ & 0.00476 & $0.373 * * *$ & -0.00099 & 0.0380 & -0.0139 & -0.0512 \\
\hline & $(0.0414)$ & $(0.117)$ & $(0.0648)$ & $(0.124)$ & $(0.0212)$ & $(0.0416)$ & $(0.0262)$ & $(0.0329)$ \\
\hline \multirow[t]{2}{*}{ Technical vocational } & -0.0282 & 0.0322 & 0.0353 & $0.128 * *$ & 0.00493 & $0.0340 *$ & 0.00476 & -0.0115 \\
\hline & $(0.0309)$ & $(0.0456)$ & $(0.0478)$ & $(0.0542)$ & $(0.0139)$ & $(0.0185)$ & $(0.0113)$ & $(0.0150)$ \\
\hline \multirow[t]{2}{*}{ Technical polytechnic } & $-0.0895 * *$ & 0.0557 & 0.0196 & $0.224^{*}$ & 0.00638 & $0.0765^{*}$ & 0.0102 & 0.00239 \\
\hline & $(0.0380)$ & $(0.126)$ & $(0.0557)$ & $(0.118)$ & $(0.0206)$ & $(0.0400)$ & $(0.0135)$ & $(0.0347)$ \\
\hline \multirow[t]{2}{*}{ Technical higher university } & 0.0207 & 0.194 & 0.00968 & 0.246 & 0.0311 & 0.0583 & 0.00363 & 0.0757 \\
\hline & $(0.0507)$ & $(0.179)$ & $(0.0672)$ & $(0.190)$ & $(0.0272)$ & $(0.0551)$ & $(0.0182)$ & $(0.0472)$ \\
\hline
\end{tabular}


Table A4 (continued)

Dependent variables

\section{Experience in the firm}

\section{Ref: $15+$ years}

$<1$ year

$1-5$ years

5-10 years

$10-15$ years

\section{Age (general experience)}

Ref: 61+ years

$<30$ years

$31-40$ years

$41-50$ years

$51-60$ years

\section{Gender}

Share of women

\begin{tabular}{l}
\hline Labor productivity \\
2009 \\
\hline
\end{tabular}

2009

$-0.0977$

(0.0751)

$-0.0782$

(0.0724)

$-0.0561$

$(0.0838)$

0.00429

(0.0849)

$\begin{array}{llll}-0.0319 & -0.0902 & 0.0400 & -0.0735 \\ (0.0407) & (0.0810) & (0.0584) & (0.0904) \\ 0.0676^{*} & 0.0927 & 0.0467 & 0.109 \\ (0.0356) & (0.0806) & (0.0523) & (0.0921) \\ 0.0245 & -0.0242 & -.0001 & 0.0106 \\ (0.0287) & (0.0805) & (0.0309) & (0.0896) \\ 0.0177 & 0.0009 & -0.0130 & 0.00793 \\ (0.0288) & (0.0802) & (0.0347) & (0.0843)\end{array}$

(0.0288)

(0.0802)

$-0.0955 * * * \quad-0.255 * * *$

(0.0241)

(0.0444)

\section{Labor productivity \\ 2013}

$-0.247 * * *$

(0.0841)

$-0.194 * *$

(0.0828)

$-0.0328$

(0.0815)

$-0.141$

(0.111)

$(0.0347) \quad(0.0843)$

$-0.0225-0.202 * *$

(0.0273) (0.0791)

\begin{tabular}{ll}
\hline $\begin{array}{l}\text { Survival } \\
\text { 2009-2013 }\end{array}$ & \\
\hline & \\
& -0.00445 \\
& $(0.0317)$ \\
& 0.0112 \\
$(0.0318)$ \\
-0.0141 \\
$(0.0331)$ \\
-0.00710 \\
$(0.0360)$
\end{tabular}

Employment growth

2009-2013
$-0.00846$
(0.0292)
$-0.00751$
(0.0297)
0.0101
$(0.0295)$
$-0.0369$
(0.0467)

$\begin{array}{llll}0.0248 & 0.161 * * * & 0.0117 & 0.106^{* * *} \\ (0.0255) & (0.0286) & (0.0201) & (0.0283) \\ 0.0356^{* *} & 0.126^{* * *} & -0.00375 & 0.0690^{* *} \\ (0.0163) & (0.0292) & (0.0194) & (0.0290) \\ 0.0595^{* * *} & 0.0996^{* * *} & -0.00973 & 0.0620^{* *} \\ (0.0140) & (0.0282) & (0.0128) & (0.0273) \\ 0.0306^{* *} & 0.0631^{* *} & -0.00121 & 0.0227 \\ (0.0133) & (0.0288) & (0.00946) & (0.0240)\end{array}$

$-0.0114-0.0338^{* *}$

$\begin{array}{ll}-0.00464 & -0.00313\end{array}$

$(0.0124) \quad(0.0158)$ 
Table A4 (continued)

Dependent variables

Labor productivity
2009

\section{Previous experience}

Ref: $15+$ years

No experience in another firm

$-0.0223$

(0.0352)

0.0524

$-0.0562$

$(0.120)$

$<1$ year

$1-5$ years

5-10 years

10-15 years
$(0.0387) \quad(0.122)$

$-0.0882 * * \quad 0.0511$

$(0.0365) \quad(0.129)$

$-0.107 * * \quad-0.138$

$(0.0480) \quad(0.139)$

$-0.0218 \quad 0.248$

$(0.0573) \quad(0.162)$

\begin{tabular}{l} 
Labor productivity \\
2013 \\
\hline
\end{tabular}

$0.0613 \quad 0.128$

$\begin{array}{ll}(0.0676) & (0.141)\end{array}$

$0.0637 \quad 0.147$

$\begin{array}{ll}(0.0659) & (0.126)\end{array}$

$0.0492 \quad 0.0679$

$\begin{array}{ll}(0.0624) & (0.128)\end{array}$

$0.0524 \quad 0.144$

$\begin{array}{ll}(0.0680) & (0.154)\end{array}$

$0.0558 \quad 0.106$

$\begin{array}{ll}(0.0685) & (0.174)\end{array}$

\section{Performance of previous emplover}

Ref: High productivity (quartile 4)

$\mathrm{n} / \mathrm{a}$

1. Low productivity

2. Medium-low productivity

3. Medium-high productivity

Number of observations

$(0.0425)$

$-0.0182$

(0.0691)

(0.0586)

$-0.458 * * *$

0.0427

(0.0764)

$(0.0451)$

$-0.452 * * *$

$0.00758-0.373 * * *$

$\begin{array}{ll}(0.0486) & (0.0888)\end{array}$

$-0.0429-0.578 * * *$

(0.0522) (0.103)

$0.0137-0.314 * * *$

$0.0632-0.262 * * *$

$(0.0428)$ (0.0725)

8501

0.231
(0.0568) (0.0770)

$-0.0229-0.210 * * *$

(0.0549) (0.0739)

6476

0.247

\begin{tabular}{l} 
Survival \\
$2009-2013$ \\
\hline
\end{tabular}

Employment growth

2009-2013

$\begin{array}{llll}-0.0723 * * * & -0.132 * * * & -0.00789 & 0.0379 \\ (0.0177) & (0.0492) & (0.0106) & (0.0499) \\ -0.114 * * * & -0.207 * * * & 0.0115 & 0.0118 \\ (0.0198) & (0.0483) & (0.0169) & (0.0509) \\ -0.0689 * * * & -0.183 * * * & 0.00149 & 0.0250 \\ (0.0187) & (0.0494) & (0.0146) & (0.0531) \\ -0.0679 * * * & -0.102 * & -0.0164 & 0.0144 \\ (0.0201) & (0.0539) & (0.0148) & (0.0637) \\ -0.0611 * * * & -0.201 * * * & -0.00464 & 0.0238 \\ (0.0223) & (0.0611) & (0.0128) & (0.0681)\end{array}$

$(0.0162)$

$-0.0568 * *$

$-0.0184$

$-0.0168$

$-0.0148$

$(0.0266)$

(0.0226)

$-0.0204$

$-0.114 * * *$

$(0.0220)$

$0.00341-0.0186$

$-0.0204$

(0.0294)

$(0.0154) \quad(0.0374)$

0.00145

$-0.0291$

$-0.0478 * * \quad-0.0490$

(0.0208)

(0.0274)

$(0.0221) \quad(0.0333)$

$\begin{array}{ll}-0.0225 & 0.0184\end{array}$

9669

(0.0281)

$(0.0141) \quad(0.0217)$
0546
6546

0.093

Pseudo-R-squared

0.0685 